\title{
The Anthropoid Postcranial Axial Skeleton: Comments on Development, Variation, and Evolution
}

\section{Citation}

Pilbeam, David. 2004. The anthropoid postcranial axial skeleton: Comments on development, variation, and evolution. Journal of Experimental Zoology Part B Molecular and Developmental Evolution 302B(3): 241-267.

\section{Published Version}

doi:10.1002/jez.b.22

\section{Permanent link}

http://nrs.harvard.edu/urn-3:HUL.InstRepos:3693472

\section{Terms of Use}

This article was downloaded from Harvard University's DASH repository, and is made available under the terms and conditions applicable to Other Posted Material, as set forth at http:// nrs.harvard.edu/urn-3:HUL.InstRepos:dash.current.terms-of-use\#LAA

\section{Share Your Story}

The Harvard community has made this article openly available.

Please share how this access benefits you. Submit a story.

\section{Accessibility}




\title{
The Anthropoid Postcranial Axial Skeleton: Comments on Development, Variation, and Evolution
}

\author{
DAVID PILBEAM* \\ Program in Biological Anthropology, Peabody Museum, Harvard University, \\ Cambridge, Massachusetts 02138
}

\begin{abstract}
Within-species phenotypic variation is the raw material on which natural selection acts to shape evolutionary change, and understanding more about the developmental genetics of intraspecific as well as interspecific phenotypic variation is an important component of the Evo-Devo agenda. The axial skeleton is a useful system to analyze from such a perspective. Its development is increasingly well understood, and between-species differences in functionally important developmental parameters are well documented. I present data on intraspecific variation in the axial postcranial skeleton of some Primates, including hominoids (apes and humans). Hominoid species are particularly valuable, because counts of total numbers of vertebrae, and hence original somite numbers, are available for large samples. Evolutionary changes in the axial skeleton of various primate lineages, including bipedal humans, are reviewed, and hypotheses presented to explain the changes in terms of developmental genetics. Further relevant experiments on model organisms are suggested in order to explore more fully the differences in developmental processes between primate species, and hence to test these hypotheses. J. Exp. Zool. (Mol. Dev. Evol.) 302B:241-267, 2004.

2004 Wiley-Liss, Inc.
\end{abstract}

"It should be remembered that systematists are far from pleased at finding variability in important characters, and that there are not many men who will laboriously examine internal and important organs, and compare them in many specimens of the same species." (Darwin, 1859, p. 45)

"Although much of evolutionary developmental biology concerns large-scale comparisons, often between classes and phyla, it seems probable that all evolutionary changes ultimately begin as intraspecific variation-whether routine, as in the case of body size, or exceptional, as in the case of the origin of limbs.................. Thus, to investigate the evolutionary origins of interspecificc differences, either in developmental genes or in the corresponding ontogenies and adult phenotypes, it is desirable to examine intraspecific variation in the same genes, ontogenies or phenotypes. So far, work in this area is rather limited." (Arthur, 2002, p. 761)

\section{INTRODUCTION}

The axial skeleton is a close to ideal model system for evolutionary developmental studies. (Strictly, the term should be "axial postcranial skeleton," because "axial skeleton" includes the skull. The shorter version is used here because of its frequent use in the developmental literature.) A considerable amount of published and unpublished data on intraspecific variation is available, especially for hominoid primates (apes and humans), and is summarized here. Phylogenetic relationships among anthropoid primates (New and Old World Monkeys, apes, and humans) are now well established (Fig. 1), and there is a modest but useful fossil record for catarrhine primates (Old World Monkeys, apes, and humans), and especially for hominins (humans and their direct ancestors and collaterals after divergence from the common ancestor of humans and chimpanzees). There are plausible functional-adaptive hypotheses to explain interspecific differences in the axial skeleton. Finally, the embryology and genetics of axial development and of some aspects of interspecific variation are well understood and can be extended hypothetically both to speculate about

\footnotetext{
Supported partly by The American School of Prehistoric Research. *Correspondence to: David Pilbeam, Program in Biological Anthropology, Peabody Museum, Harvard University, Cambridge, MA 02138. E-mail: pilbeam@fas.harvard.edu

Received 27 October 2003; Accepted 1 April 2004

Published online in Wiley Interscience (www.interscience.wiley. com). DOI: $10.1002 /$ jez.b.22
} 


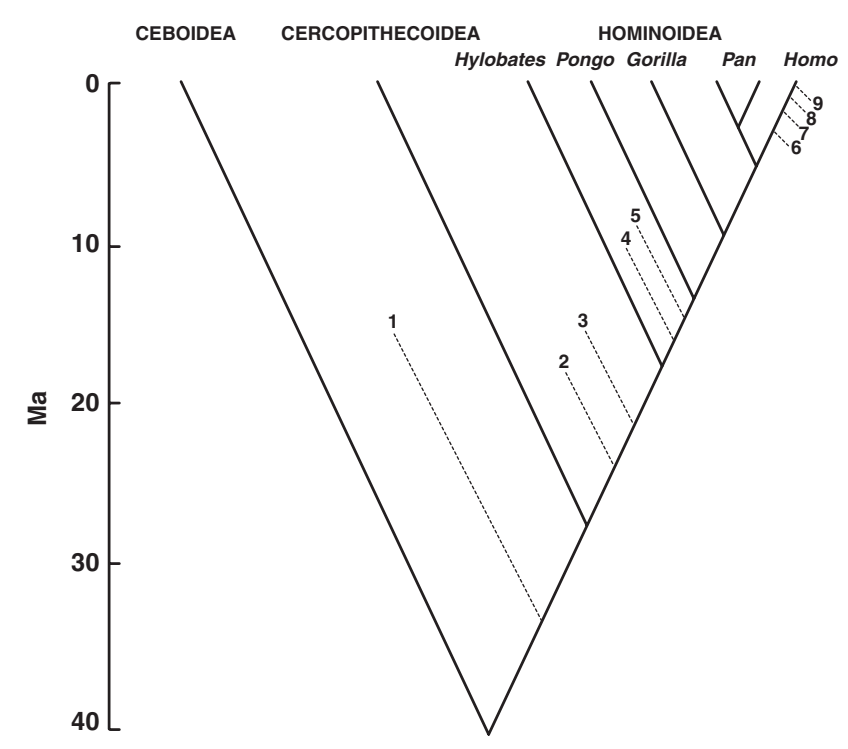

Fig. 1. Schematic of anthropoid phylogenetic and temporal relationships, showing Ceboidea, Cercopithecoidea, and Hominoidea; hominoid genera Hylobates, Pongo, Gorilla, Pan, and Homo; fossil taxa noted in text with tentative phylogenetic placement: 1-Pliopithecus, 2-Proconsul, 3-Nacholapithecus, 4-Dryopithecus, 5-Oreopithecus, 6-Australopithecus, 7Homo erectus, 8-Homo heidelbergensis, 9-Homo neanderthalensis.

the genetic bases of intraspecific variation and to frame an agenda for further research.

The hominoids are an important group for such studies because large samples are available to document what is a surprising amount of intraspecific variation. An added bonus is that, being tail-less, or having a very reduced caudal region (coccyx) which is generally preserved in skeletal collections, total numbers of vertebrae are readily counted in hominoid species. This is critically important information in determining how variability in the axial skeleton is generated.

The axial skeleton is an essential component of and contributor to a species' positional repertoire (Slijper, '46; Hildebrand, '88). For example, the differences between bipedal humans and suspensory and quadrupedal apes are well reflected in differences in vertebral numbers within regions of the vertebral column, as well as differences in morphology. A few simple parameters capture well some of the important interspecies differences. With only a few exceptions, mammalian genera have a neck region comprising a quite constant modal number of seven cervical vertebrae, with variants from seven being very rare (e.g. Schultz, '61; Solounias, '99 and Tables in this paper). One of the most important parameters differentiating taxa is the number of vertebrae separating the placement of forelimb and hindlimb; this correlates closely with the positions of the brachial and lumbosacral plexuses. The brachial plexus in amniotes usually comprises four or five spinal nerves, the more cranial three or four being the most caudal cervical nerves, the most caudad the first thoracic (Burke et al., '95). Because the cervical region is fixed at seven vertebrae in most mammalian Orders (Schultz, '61), forelimb and brachial plexus positions are therefore relatively invariant.

The lumbosacral plexus in catarrhines comprises the last two or three lumbar nerves and the first one to three sacrals, regardless of numerical position in the vertebral column, and is a little more positionally variable (Swindler and Wood, '73), although intraspecific sample sizes are inadequately small. The separation of brachial plexus plus forelimb from lumbosacral plexus plus hindlimb reflects the total of thoracic plus lumbar vertebrae (Todd, '22). For example, within Primates between species thoracic plus lumbar number varies from modes of 16 in Pongo, the orangutan, to 23 in the lorisid, Nycticebus (Schultz, '61). (Body size adjusted vertebral length can also vary: cursorial cercopithecoids, most with 19 thoracics plus lumbars, have relatively longer vertebrae than the quadrumanous, large bodied deliberate climber Pongo.) Thoracic plus lumbar vertebral totals also vary within species, for example from 16 to 18 in humans, 15 to 18 in African apes, 15 to17 in orangutans, and so forth. Because the position of brachial plexus and forelimb is effectively invariant, one major variable is the positioning of the lumbosacral plexus and hindlimb.

A second important parameter of interspecific variation involves the position of the thoraciclumbar boundary, because this separates two distinct structural functional regions. The boundary can be recognized and defined in two ways: first, the traditional way, in which thoracics are the rib-bearing vertebrae (Schultz, '61), and second, the functional way, in which terminal thoracics with lumbar-type zygapophyseal articulations are counted as functionally equivalent to lumbars (Erikson, '63). Take, for example, the contrast between most cercopithecoid monkeys and the chimpanzee, Pan. Traditionally defined, the monkeys have T12 and L7, and Pan, T13 and L3 or 4. Functionally defined, monkeys have T9 and L10 while Pan remains the same as when defined traditionally. Most humans have T12 and L5 defined either way. Numbers of sacrals and caudals also vary, although these variations are arguably less significant functionally. 
Summarizing, the principle variations reside in the number of vertebrae separating forelimbs and hindlimbs, including their nerve supplies, and in the position of the thoracic-lumbar boundary. Hence my particular focus is in reviewing what is known about the genetic determinants of these variables.

Both between and within species there are differences in the identity of a particular numbered vertebra. As noted above, most humans have T12 and L5 while most chimpanzees have T13 and L4; hence, in almost all humans the twentieth vertebra is a lumbar while in the majority of chimpanzees it is a thoracic. Is this due to the "loss" of a thoracic in humans? Or to the "loss of a lumbar in chimpanzees? Or is the difference due to a shift in the identity of the 20 th vertebra? That is, are such differences meristic or homeotic (Ahn and Gibson, '99c; Carroll et al., 2001)? Are they due to transformations of identity (transpositions) of a particular vertebra leading to regional boundary shifts (homeotic), or are they due to loss of a segment (meristic)? What then are the homologies of that $20^{\text {th }}$ vertebra, which is a first lumbar in humans and a last thoracic in chimpanzees? One can ask the same question about intraspecific variation: is the difference between chimpanzees with three or four lumbars homeotic or meristic?

Such questions can now be more easily answered given the increasing amount of relevant research on the genetics of axial development, and one goal of this paper is to summarize some of that research. Data on intraspecific phenotypic variation is also important, especially from hominoids for which accurate total vertebral counts are possible. We are interested here in explanations for variation in two developmental processes with significant phenotypic consequences: segmentation, associated with the total number of vertebrae, and specification, associated with differences between vertebral regions. In describing intraspecific and interspecific variation in the hominoid axial skeleton and reviewing briefly the current state of understanding of the embryology and developmental genetics of the vertebrate axial skeleton, I hope to stimulate both further research into the genetic complexities of intraspecific variation, and experimental approaches to understanding genetic bases for critical phenotypic changes in hominoid evolution-especially in hominins. As Carroll noted recently (2003), “......morphological evolution in hominins was not special, but the product of genetic and developmental changes typical of other mammals and animals."

\section{DEVELOPMENTAL BASICS}

\section{Somite and vertebral development}

Vertebrae are derived from unsegmented paraxial or presomitic mesoderm lying either side of the notochord, generated from the tailbud region of the embryo (Christ et al., 2000; Pourquié, 2001; Saga and Takeda, 2001; Kornak and Mundlos, 2003). During embryogenesis, the cranial region develops first, and new presomitic mesoderm is added caudally. This presomitic mesoderm segments along the cranial-caudal axis into somites, with more cranial somites forming first, followed by successively younger somites caudally. Somitic cells facing surface ectoderm differentiate into the dermomyotome, while more medial cells form the sclerotome. The dermomyotome in turn differentiates into the dermotome (future inner dermis) and myotome (future muscles). The sclerotome undergoes a second segmentation, termed resegmentation, in which the cranial and caudal halves of each somite separate and reunite with neighboring caudal and cranial somitic halves to form future vertebrae and ribs. In amniotes the first four-and-a-half somites are incorporated into the occipital region of the skull. The caudal half of the fifth somite is incorporated into the body of the atlas, which also includes the cranial half of the sixth somite, and so on.

As noted, presomitic mesoderm, and the somites which condense from it, is generated along a cranial-caudal axis both spatially and temporally. In the mouse (Burke et al., '95), at embryonic day 9 (E9) the forelimb bud extends from somite level 8-9 to 13-14 while the hindlimb bud, which appears at E10, extends from 23-24 to 28-29. Three days later at E13, the forelimb bud has shifted minimally (somites 8-9 to 15-16) but the hindlimb bud has moved considerably caudally to span somites 29-30 to 34-35. By this stage, or very soon after, somitogenesis is almost complete cranially, but resegmentation and vertebral formation is still underway caudally.

The mouse, like the great majority of mammals, almost invariably has seven vertebrae in the cervical region, formed from somites 5-6 through 11-12 (Burke et al., '95). In the mouse the thoracic region (with a modal number of thirteen vertebrae) is formed from somites 12-13 through 24-25, the lumbar region withmodal six vertebrae is derived from somites 25-26 through 30-31, the sacrum with four vertebrae forms from somites 31-32 through 34-35, while the caudals begin at 
somites 35-36. In contrast (Burke et al., '95), the chick has fourteen cervicals, formed from somites 5-6 through 18-19, and seven thoracics, derived from somites 19-20 through 25-26. Both the total numbers of somites, and hence vertebrae, and the ultimate identity of a particular somite, vary between species. They also vary within species. There are effectively two separate but linked processes to be considered: somite number and somite identity.

\section{Segmentation and specification}

We can find good examples of these processes, segmentation and specification, within the Primates. As noted, hominoids are especially useful because, being tailless, total vertebral and hence original somite counts can be obtained accurately from museum collections. For example (Tables 6 and 11), total vertebral (and original somite) numbers vary from 29 to 33 vertebrae in Pongo, the orangutan, while in Pan paniscus, the bonobo, they vary between 33 and 35 . The identity of particular vertebrae also varies between and within species. For example, the 21st vertebra (somites 25-26) in Pongo is the second lumbar while in the bonobo it can be either the last thoracic, the first lumbar, or the second lumbar.

The more we understand about the developmental mechanisms underlying the production of somites, the determination of their number, the specification of the future vertebral identity of a particular somite, and their patterns of inheritance, the more complete can be our descriptions and explanations of evolutionary change, in particular of the intraspecific variation from which evolutionary change is shaped.

There are several excellent recent reviews of somitogenesis (Christ et al., 2000; Pourquié, 2001; Saga and Takeda, 2001; Kornak and Mundlos, 2003). Many genes are known to be involved (and more surely remain to be identified). Genes of the Notch/Delta signalling pathways are critical in at least two phases of somite production (Dale et al., 2003; Stollewerk et al., 2003). First, as an important component of the so-called segmentation clock, which is cyclically active in presomitic mesoderm in determining the future somites as they are generated along the cranial-caudal axis. Second, in establishing the somite boundaries during separation from the unsegmented presomitic mesoderm. Genes of the Notch/Delta pathway are essential upstream links to the Hox genes, which are also cyclically active during the pre- somitic phases of somitogenesis (Zákány et al., 2001). In addition, $F G F 8$ is expressed in caudal presomitic mesoderm and is important in determining segment boundaries as well as axial identity (Vasilauskas and Stern, 2001; Dubrulle et al., 2001; Dubrulle and Pourquié, 2004). Experimental manipulation of the amount or position of expressed FGF8 in presomitic mesoderm can change somite number (Dubrulle et al., 2001).

While the same Notch/Delta genetic pathways are expressed repeatedly as each new somite is generated, the mature axial skeleton is made up of distinct regions in which elements are more-orless similar to each other within regions and different from those in other regions. The Hox genes are currently the only known candidates exhibiting regional expression differences in the paraxial mesoderm and somites that are correlated with these phenotypic patterns. It is now well established that Hox genes are very important, although not sole, contributors to the final identity of particular vertebrae (for example, Haack and Kessel, '94; Gellon and McGinnis, '98; Burke and Nowicki, 2001).

\section{Hox genes}

Transcription factors controlling the identity of different body segments were first discovered in Drosophila because of their role in homeotic transformations (Lewis, '78) and were subsequently shown to be widely involved in patterning in a variety of tissues. In amniotes four clusters of Hox genes have been identified, labelled A through $\mathrm{D}$, each cluster on a separate chromosome. There are 39 Hox genes in tetrapods. Genes in each Hox cluster are numbered 1 through 13 in 3 ' to 5' order, each number identifying a paralogue group in which genes in the different clusters exhibit close sequence similarity, reflecting their origins via gene duplication from a primitive single complex (Gellon and McGinnis, '98; Carroll et al., 2001; Burke and Nowicki, 2001).

Hox genes are expressed in a variety of tissues in addition to the axial skeleton, including neural tube, gut, reproductive system, and limbs. Because they are expressed in such a diverse range of tissues and are so critical to development, they are under strong purifying selection, and natural Hox mutants are relatively rare (Veraksa et al., 2000; Kornak and Mundlos, 2003). There is some experimental evidence to support the hypothesis that Hox genes evolved originally in the context of 
axial patterning (e.g., Spitz et al., 2001). The correct coordination of expression of the Hox gene complexes depends on the maintenance of a complicated array of both trans- and cis-regulatory sequences, including promotors, tethering elements, enhancers, insulators, and silencers, and their interaction through enhancer sharing, selective interactions between enhancers and promotors, and promotor competition for enhancers (Sharpe et al., '98; Belting et al., '98a; Hérault et al., '99; Calhoun and Levine, 2003; Levine and Tjian, 2003). The complicated nature of such networks probably accounts for the stability and ubiquity of Hox complexes in vertebrates.

In patterning the axial skeleton, the more 3' the gene, the more cranial is its expression domain in presomitic mesoderm and somites, and conversely, the more 5' the gene, the more caudal the expression domain. Also, the more 3' the gene, the earlier is it expressed, and the more $5^{\prime}$ the gene, the later is it expressed. The spatial and temporal sequences of expression are correlated with 3' to 5' gene order, a phenomenon described as colinearity (e.g., Haack and Kessel, '94). Hox genes are expressed in overlapping domains along a cranial-caudal gradient, showing sharper anterior expression boundaries and more diffuse posterior boundaries. Lengths of these expression domains vary across Hox genes. Expression domains form complex overlapping patterns that specify the identities of each vertebra (Haack and Kessel, '94, Burke et al., '95).

An elegant comparison of mouse and chick has shown that the Hox code can operate independently of somite number (Burke et al., '95; Belting et al., '98b). As noted earlier, chick and mouse have approximately the same number of cervicalplus thoracic vertebrae $(14+7$ and $7+13$, respectively), but cervical/thoracic boundaries fall at different vertebral positions: the first thoracic is the 15th chick vertebra but only the 8 th in the mouse. Axial Hox maps were constructed for the two species (Burke et al., '95) and showed that expression boundaries for homologous Hox genes were consistently associated with vertebral morphology and not with somite (and hence vertebra) number. For example, Hoxc-6 is expressed at the cervical/thoracic boundary in both species, at around somite 12 in mouse and somite 19 in chick. Hoxa-9 and Hoxc-9 are expressed close to the thoracic/lumbar boundary, near somite 24 in mouse and somite 25 in chick. Thus axial identity depends not only on spatial colinearity but also cranial to caudal expression position, which reflects timing of when a gene is first expressed relative to the production of somites: more 3' genes are expressed earlier with the oldest somites. Temporal colinearity is an essential complement to spatial colinearity.

The segmentation clock, somitogenesis, and Hox gene expression are linked, with the Hox complex downstream of the gene systems primarily involved in somite production. A recently discovered gene, $G d f 11$, is also important, acting upstream of Hox genes to regulate axial patterning (Dubrulle et al., 2001). It does so in two ways, by influencing the number of somites generated and by causing homeotic shifts which change vertebral identity. In addition, mammalian homologues of the Drosophila genes Trithorax and Polycomb-group, including, respectively, $M l l$ and $B m i-1$, act upstream of Hox to maintain gene expression or repression (Hanson et al., '99). Finally (although this by no means completes the catalogue of known or probable upstream regulators of $H o x$, it has been known for some time that retinoic acid has homeotic activity and that it acts upstream of Hox (Kessel, '92). In addition to those acting upstream, many genes act downstream of $H o x$ genes (Zhao and Potter, 2001).

Summarizing, many genes are involved in the processes of somite formation and specification; these processes are inter-connected, although both a study of the genetic processes and of the patterning of intraspecific vertebral variation discussed earlier show that the connection is not absolute. What follows is a brief review of experiments relevant to understanding some of the genetic components of variation in vertebrate number and identity. The experiments study modifications to the expression of various genes, taken one at a time. In virtually all such experiments, the resultant phenotypic effects show variation, reflecting the fact that many genes are involved in the development of phenotypes ("genetic background") and that isolating and controlling for the effects of single genes in experiments still faces the problem of uncontrolled variability in other components of the genetic networks, and in the genetic background of the inbred laboratory strains.

\section{Knockout experiments}

Beginning with knockout experiments in which genes are silenced (not expressed), Gdf11, which acts upstream of the Hox complex, affects both somite number and somite identity (McPherron 
et al., '99). The "normal" laboratory mouse populations used in the experiment varied in the number of lumbar vertebrae: precaudal axial formulae were 7:13:6:4 (representing numbers of cervical, thoracic, lumbar, and sacral vertebrae, respectively) for around $75 \%$ of the sample and $7: 13: 5: 4$ for the remaining $25 \%$. These mice average around 50 somites each. Mutant mice with targeted deletions of $G d f 11$ were generated and used to produce heterozygous $G d f 11+/$-and homozygous $G d f 11$-/-mice (the latter die within 24 hours of birth). Almost all the heterozygotes had $7: 14: 6: 4$ phenotypes, although a very small fraction were $7: 14: 5$ or $7: 13: 6$, and hence were significantly less variable than normal homozygotes. Mutant homozygotes showed considerable variability, with significantly more thoracic vertebrae (17 or 18 ) and lumbar vertebrae ( 7 to 9 ) in various combinations; the modal formula was present at less than $70 \%$ frequency. Thus, hindlimbs were shifted posteriorly. Changes in vertebral identity were correlated with shifts in the expression domains of several Hox genes: Hoxc-6, $-8,-10$, and -11 had their domains either extended or caudally shifted entirely. In addition to the anterior homeotic transformations, with vertebrae taking on the characterisitics of more cranial elements, there were also slight reductions in the total number of somites in the null homozygotes. Somite number and future identity were uncoupled in ways different from variation seen in normal populations, where decreased somite/vertebra number is positively correlated with decreased rather than increased thoracic plus lumbar number (andhence normally an anterior rather than posterior shift in hindlimb position).

In similar experiments with null mutants of $M l l$, which also acts upstream of Hox, only heterozygotes were viable (Yu et al., '95). Normal homozygotes exhibited variation in axial patterns, with low frequencies of anterior transpositions in the cervical and anterior thoracic regions, low frequencies of last thoracic posterior transpositions, and higher frequencies (around one third) of posterior transpositions of the last lumbar (vertebra $26 \mathrm{~S} 1$ rather than L6). The mutant heterozygotes showed considerably higher frequencies of all these variants, reflecting shifts in expression boundaries of Hoxa-7 and Hoxc-9. Genes of the $C d x$ family also have an influence on Hox expression (Allan et al., 2001). Finally, both endogenous and exogenously administered retinoic acid (RA) influences Hox expression and vertebral identity, reflecting the fact that $\mathrm{RA}, M l l$, and response elements are present in the regulatory elements of at least some Hox genes (Kessel, '92; Zákány etal., '97). Depending on the timing and amount of the dose, RA can induce both anterior and posterior transformations. $C d x$ can itself also be a target of retinoic acid, providing an indirect pathway through which vertebral patterning can be influenced by RA (Allan et al., 2001).

In addition to knockout experiments involving these and other genetic elements upstream of the Hox complex, there have been many experiments involving both Hox over-expression and knockouts, leading to gain- and loss-of-function phenotypes (anterior and posterior transpositions). As noted, natural mutants in exons of Hox genes are rare (Goodman and Scandler, 2001; Kornak and Mundlos, 2003). Hox gene activities can be mutually redundant, complementary, or synergistic, and not all mutant genotypes yield detectable phenotypic changes. Knockouts can involve more than the axial skeleton, because Hox genes are expressed in many tissues, and phenotypes often include changes in the patterning of limbs and other tissues as well as the axial skeleton (Davis and Capecchi, '94; Favier et al., '95).

Over-expression and knockout experiments have demonstrated the important role played by the Hox genes in axial patterning. These systems are relatively conservative across a wide range of animal forms (Burke et al., '95). Wellik and Capecchi (2003) knocked out all mouse Hox10 and Hox11 paralogues (groups a, c, and d) and showed that, in addition to limb changes, paralogues function in the axial skeleton to suppress the formation of thoracic-type ribs caudal to the thoracic region, while Hox 11 paralogues partially suppress the action of the Hox10 group in the sacral region allowing the development of rib-like processes connecting to the ilium. Of particular interest in considering the positioning of the hindlimb, in Hoxa-10 and $d-10$ single and double heterozygotes and homozygous mutants, the sacrum may be shifted one or two segments caudally (Wahba et al., 2001). The ilium and lumbosacral plexus are nonetheless appropriately configured relative to the sacrum, indicating the role of these Hox genes in correctly positioning the hindlimb and its nerve supply.

\section{Transgenic experiments and regulatory elements}

It seems likely that as we seek the causes of differences between closely related species and of 
variation within species, variation in regulatory regions will prove to be most important (Gellon and McGinnis,'98). It is well established that many cis- regulatory factors such as enhancers, insulators, tethering elements, silencers, and promotors are involved in both the expression of particular genes and in the integration of complex networks like the Hox system (Sharpe et al., '98; Belting et al., '98a; Hérault et al., '99; Calhoun and Levine, 2003; Levine and Tjian, 2003). Differentiation in the regulatory apparatus allows a relatively small number of genes, expressed in many different tissues, to have markedly different effects in those tissues. Several experiments have interesting implications for our considerations of anthropoid inter- and intraspecific axial variation (e.g., Charité et al., '95).

For example, the Ruddle group (Shashikant and Ruddle, '96; Bradshaw et al., '96), working with the Hoxc-8 gene which is expressed in future thoracic somites, identified some of the elements regulating gene expression, in particular regions separated $3 \mathrm{~kb}$ and $11-20 \mathrm{~kb}$ from the gene, regulating respectively early and late expression. The former, early enhancer region is around 200 bp long and directs Hoxc-8 anterior limit expression to neural tube, paraxial mesoderm, and lateral plate mesoderm. Within the $200 \mathrm{bp}$ region, five short (6-7 bp) elements, labelled A through E, act combinatorially to regulate expression separately in the three tissues. As noted, Hoxc- 8 is expressed in the future midthoracic region. Remember that axial formulae differ between mouse and chick, the former having 7 cervicals and 13 thoracics, the latter 14 cervicals and 7 thoracics. In the mouse, Hoxc- 8 is expressed between $\mathrm{S} 15$ and S21 (future T5 to T11) while in chick its expression domain lies between S21 and S25 (future T3 to T7). Thus Hoxc-8 expression is both more posterior in chick relative to mouse, and it spans fewer somites. Expression is first noted at embryonic day 8 in mouse embryos with 6 to 7 somites, whereas expression is developmentally delayed in the chick and is not detectable until the 18-19 somite stage, correlated with its more caudal expression domain (Belting et al., '98b). Belting et al. ('98b) incorporated a critical $151 \mathrm{bp}$ of the chick early enhancer region into transgenic mice and showed that Hoxc-8 expression shifted posteriorly in both neural tube and paraxial mesoderm. The relevant mouse and chick regions differed by around $20 \%$ in nucleotide sequence, with differences falling both between and within elements A through E. Variation in these regions could be one cause of variation in the length of the thoracic region between and within species, and hence in position of the thoracolumbar boundary.

Two papers from the Duboule group take a similar approach with Hoxd-11 transcription (Zákány et al., '97; Gérard et al., '97), gene expression being associated with the lumbosacral region. A 900 bp region 3' of Hoxd-11 contains two regulatory elements, RVIII and RIX, which are involved in the timing and positioning of Hoxd-11 boundaries. Hoxd-11 is expressed in limbs, the urino-genital system, and the paraxial mesoderm at the lumbar-sacral boundary. Hoxd-11 is first detected in the embryo at E9 (somite 14 stage) five days before the sacrum can be identified at E14. Elements RVIII and RIX act together to effect precise activation and positioning of Hoxd-11 expression limits at the lumbar-sacral transition (pre-vertebra 27). Targeted mutations of these regulatory regions cause mispositioning of expression boundaries. RVIII is required for initial activation of gene expression, while RIX acts as a transcriptional silencer limiting anterior expression of both Hoxd-11 and Hoxd-10; they act only in paraxial mesoderm (Zákány et al., '97; Gérard et al., '97). When RVIII is deleted, Hoxd-11 expression is delayed by 24 hours (Zákány et al., '97). Although normal expression patterns are subsequently restored, a significant percentage of mutant homozygotes show posterior transpositions at the lumbar-sacral boundary, with the 27 th vertebra, normally the first sacral, transposed into either an abnormal sacral or a 7th lumbar vertebra. Targetted mutations to RIX, adjacent to RVIII, misposition expression boundaries of both Hoxd-11 and Hoxd-10. Transgenic mice were constructed by replacing most of mouse RVIII and RIX with the homologous region in zebra fish (Danio rerio). Activation of the Hoxd complex takes two days in the mouse but only hours in zebra fish. The earlier expression of Hoxd-11 in transgenic mice results in a cranial shift in the lumbar-sacral boundary; over half of homozygotes and around a third of heterozygotes have five rather than six lumbar vertebrae. Mutations in these regulatory regions could be a cause of the kinds of lumbosacral variation seen in anthropoids: for example, cercopithecoids (Old World Monkeys) have seven lumbar vertebrae while small hylobatids (hominoids, the gibbons) typically have five lumbars (Schultz, '61).

In another experiment by the Duboule group (Spitz et al., 2001), transgenic mice were produced carrying a $120 \mathrm{~kb}$ fragment comprising most of the 
human HOXD complex. Recovered embryos showed expression of human transcripts only in the axial skeleton and not in the limbs, indicating that regulatory elements associated with expression in limbs were located primarily outside the fragment. A high frequency of embryos showed five rather than six lumbar vertebrae (the former being the modal human number and the latter the modal mouse number). But the expression patterns of three monitored genes, $H O X D-4,-11$, and -13 , were identical to those of normal mice. Spitz et al. (2001) suggest that the human genes are overexpressed relative to those of mice, and that this could raise the normally low expression levels immediately anterior to the more robust levels defining anterior expression boundaries, causing an anterior transposition at the lumbar-sacral boundary. In addition, mice carrying a deletion of Hoxd-11 through Hoxd-13 show seven rather than six lumbars, and another transgenic mouse with both the deletion and the human HOXD rescued the usual mouse six lumbars.

This experiment is of interest in that, despite the fact that expression of the $H O X$ complex is slower in humans than in the mouse, the lumbar region is still shortened in the transgenics, implying that specification of the lumbar-sacral transition is determined not later but rather earlier in the transgenics. It is also of interest in that detectable expression domains in transgenics do not correspond exactly with phenotypes.

A possibly analogous situation is reported by Ahn and Gibson ('99a, b, c) in the three spine stickleback. Hox genes are expressed in the paraxial mesoderm and somites of these fish in an overlapping 3' to 5' pattern as in tetrapods, but without the marked vertebral regional differentiation characteristic of the latter. Benthic and limnetic stickleback species vary in types of vertebrae and median skeletal elements. Breeding experiments on laboratory populations established from the two species showed a considerable genetic component to axial variation, both meristic and homeotic, within and between species. Expression patterns of three Hox genes were examined, Hoxb-5, Hoxa-9, and Hoxa-10. Patterns were similar in the two species, despite phenotypic differences between them; in this case there is no obvious close association between vertebral phenotypes and Hox distribution patterns. This may be for a variety of reasons (Ahn and Gibson, '99b). For example, perhaps other genes acting downstream of the Hox complex or other genes in the complex are involved in precise axial specification.
Or perhaps fish and tetrapods associate genetic patterns and phenotypes in different ways, possibly reflecting contrasting downstream activity.

These and other experiments show that timing of onset and cessation of gene expression is critical, because they affect both position and extent of expression domains and these are in turn linked to ultimate vertebral identity. Transcriptional heterochrony, i.e., changes in relative timing of these actions, is clearly very important in effecting the changes seen between species and, by inference, variation within species. Further experiments on regulatory elements with transgenics can be anticipated to throw light on the relatively minor yet critical differences among Primates.

As noted earlier, a number of genes act upstream of the Hox complex during axial development. Downstream Hox targets in paraxial mesoderm are not well understood. Zhao and Potter (2001) showed that there were over 100 diagnostic gene expression changes downstream of mouse Hoxa-13 in a homeobox swap experiment (in which the homeobox of Hoxa-11 was replaced with that of Hoxa-13); for example, the uterus showed clear homeotic transformation towards a pattern more characteristic of cervix and vagina.

\section{Gene expression and the iliosacral complex}

Genes of the Hox complex are not expressed in the ilium, the pelvic bone which articulates with the lateral processes of the sacral vertebrae. The homeobox containing gene Emx2 is expressed in the developing ilium but is not transcribed in sacral vertebrae (Pellegrini et al., 2001). Emx2 homozygous mutants fail to develop the ilium except for portions forming the acetabulum and a sliver of the iliac crest. They also lack the normally extensive sacral transverse processes, suggesting that the presence of an ilium is necessary to induce formation of sacral lateral processes (Pellegrini et al., 2001). However, given the role of Hox genes in positioning the lumbar-sacral plexus and hindlimb (Wahba et al., 2001), and the fact that in gene and enhancer knockout and mutation experiments (Wellik and Capecchi, 2003) anterior or posterior transpositions of the lumbarsacral transition generally involve appropriate positioning of the ilium, the two genetic systems must be coordinated during development.

\section{Development summary}

In summary, there is currently a good understanding of the basic developmental genetics of the 
axial skeleton in model animals, and especially (given the focus of our interest) in the laboratory mouse, the model organism phylogenetically closest to Primates. Somitogenesis is well understood, and although there are clearly important elements upstream as well as downstream, it is equally clear that the Hox complex (both expressed genes and their regulatory elements) plays a central role in axial development and vertebral specification. Hox genes are expressed in overlapping domains along the developing axial skeleton in ways that correlate with ultimate identity. Temporal and spatial colinearity of Hox gene expression means that the timing of onset and duration of expression, prior to and during somitogenesis, is critical for determining regional vertebral boundaries. Thus in the phylogenetically broad comparison of mouse and chick, differences in the relative positioning of regional boundaries correlate with differences in the expression patterns of Hox genes, and these expression differences can be linked experimentally to timing and duration of gene expression. On a narrower scale, transgenic and mutagenic experiments with mice show that small intraspecific differences in vertebral formulae are effected by heterochronic shifts. Of particular interest is the role of regulatory elements such as enhancers, and evidence that small genetic differences in quite restricted genomic regions can effect the kinds of axial shifts important to our analysis here. It is this intraspecific variation on which natural selection acts.

\section{PRIMATE MORPHOLOGICAL DATA}

Data come principally from the extensive records of Adolph Schultz, augmented by personal observations and generous personal communications from colleagues. Schultz's work on the vertebral column and pelvis is best known from his 1961 monograph. This provides only mean numbers of vertebrae per axial region, along with some relative frequencies. Individual specimen data of a kind necessary for this study are available in Schultz ('30, '33) and a limited number of other works (e.g., Flower, 1884; Bardeen, '04; Hasebe, '13), but the bulk of the material reported here comes from unpublished Schultz individual specimen datasheets kindly made available by Professor R. D. Martin. I follow Schultz ('61) in using simple and traditional criteria for defining vertebral types, including "half vertebrae" - for example a vertebra with a rib on one side only would be described as $1 / 2 \mathrm{~T}$.
I recognize that this simplifies the actual phenotypic variation in natural populations (e.g., Barnes, '94), but do not believe this is to the detriment of the analysis.

Most data are reported in the form of the axial pattern or formula (Burke et al., '95), which records the numbers of elements in each of the traditionally defined regions of the vertebral column (cervicals, thoracics, lumbars, sacrals, and caudals when available). For example, the modal human (a Japanese sample from Hasabe, '13) precaudal formula is 7:12:5:5 while the modal total vertebrae formula is $7: 12: 5: 5: 4$. Equivalent chimpanzee formulae are 7:13:4:6 and 7:13:4:6:3. (It is important to recognize that in each case these formulae represent only a small fraction of normal intraspecies variation.) Reliable data on the number of caudals for large samples are difficult to obtain on tailed species because of curatorial problems with museum collections. This is why the Hominoidea are a particularly useful source of information on an individual's total number of vertebrae, and hence original somite number.

Raw data on populations reported here and summaries of other published data will be published elsewhere and are also available on request. Tables 1-15 record axial profiles for Hominoidea. Both precaudal (cervicals through sacrals) and total vertebrae (cervicals through caudals) are summarized. In most cases the sample size for the latter is smaller than for the former. I treat the two Gorilla samples separately (western or lowland gorillas, G. g. gorilla, and eastern lowland and mountain gorillas, G. g. graueri/beringei) because they are at least as different genetically as the two Pan species (Ruvolo, '97b; Gagneux et al., '99). Unfortunately, the G. g. graueri/ beringei sample of 14 is too small (Table 9) to reliably document variation. Only two species of Hylobates have large enough samples for detailed analyses (Tables 12-15), although data on other Hylobates species are included along with summary statistics for all hominoids in Table 16. Tables 17 and 18 present summary statistics for Cercopithecoidea (Old World Monkeys) and Ceboidea (New World Monkeys) respectively. Adequate samples of ceboids (Table 18) are not available, the largest published sample being 28 Saimiri sciureus (Clauser, '80), but larger samples are available for several cercopithecoid species (Table 17), including the spectacular 882 for Macaca fuscata (Aimi, '94)! Finally, for comparison I include a large sample of the cricetid rodent, 
TABLE 1. Homo sapiens precaudal formulae in order of frequency $(n=181)$

\begin{tabular}{|c|c|c|c|c|}
\hline Cervical & Thoracic & Lumbar & Sacral & $\%$ \\
\hline 7 & 12 & 5 & 5 & 57.5 \\
\hline 7 & 12 & 5 & 6 & 22.1 \\
\hline 7 & 13 & 4 & 5 & 2.8 \\
\hline 7 & 12 & 6 & 5 & 2.2 \\
\hline 7 & 13 & 4 & 6 & 1.7 \\
\hline 7 & 12.5 & 4.5 & 6 & 1.7 \\
\hline 7 & 12 & 4.5 & 5.5 & 1.1 \\
\hline 6.5 & 12.5 & 5 & 5 & 1.1 \\
\hline 7 & 12 & 4 & 6 & 1.1 \\
\hline 7 & 13 & 5 & 5 & 1.1 \\
\hline 7 & 12 & 5.5 & 5.5 & 1.1 \\
\hline 7 & 13 & 4.5 & 5.5 & 0.6 \\
\hline 7 & 13 & 5 & 6 & 0.6 \\
\hline 7 & 11.5 & 43 & 5 & 0.6 \\
\hline 7 & 12 & 4 & 5 & 0.6 \\
\hline 6.5 & 12.5 & 5 & 6 & 0.6 \\
\hline 7 & 12 & 5.5 & 4.5 & 0.6 \\
\hline 7 & 12 & 6 & 4 & 0.6 \\
\hline 7.5 & 12.5 & 5 & 5 & 0.6 \\
\hline 7 & 11 & 5 & 6 & 0.6 \\
\hline 6.5 & 11.5 & 5 & 6 & 0.6 \\
\hline 7 & 11 & 6 & 5 & 0.6 \\
\hline 7 & 11.5 & 4.5 & 5.5 & 0.6 \\
\hline
\end{tabular}

TABLE 2. Homo sapiens total vertebrae formulae in order of frequency $(n=109)$

\begin{tabular}{lccccccc}
\hline Cervical & Thoracic & Lumbar & Sacral & Caudal & Total & $\#$ & $\%$ \\
\hline 7 & 12 & 5 & 5 & 4 & 33 & 37 & 33.9 \\
7 & 12 & 5 & 5 & 5 & 34 & 32 & 29.4 \\
7 & 12 & 5 & 6 & 4 & 34 & 11 & 10.1 \\
7 & 12 & 4.5 & 5.5 & 4 & 33 & 3 & 2.8 \\
7 & 12.5 & 4.5 & 6 & 4 & 34 & 3 & 2.8 \\
6.5 & 12.5 & 5 & 5 & 4 & 33 & 2 & 1.8 \\
7 & 12 & 5 & 6 & 3 & 33 & 2 & 1.8 \\
7 & 13 & 4 & 5 & 4 & 33 & 2 & 1.8 \\
7 & 13 & 4 & 5 & 5 & 34 & 2 & 1.8 \\
7 & 12 & 5 & 5 & 2 & 31 & 1 & 0.9 \\
7 & 11.5 & 4.5 & 5 & 4 & 32 & 1 & 0.9 \\
7 & 12 & 5 & 5 & 3 & 32 & 1 & 0.9 \\
7 & 12 & 4.5 & 5.5 & 3 & 32 & 1 & 0.9 \\
6.5 & 11.5 & 6 & 6 & 3 & 33 & 1 & 0.9 \\
7 & 11.5 & 5.5 & 5 & 4 & 33 & 1 & 0.9 \\
7 & 12 & 4 & 6 & 4 & 33 & 1 & 0.9 \\
7 & 12 & 5.5 & 5.5 & 3 & 33 & 1 & 0.9 \\
7 & 12 & 6 & 4 & 4 & 33 & 1 & 0.9 \\
6.5 & 12.5 & 5 & 5 & 5 & 34 & 1 & 0.9 \\
7 & 12 & 5.5 & 4.5 & 5 & 34 & 1 & 0.9 \\
7 & 12 & 6 & 5 & 4 & 34 & 1 & 0.9 \\
7 & 13 & 4.5 & 5.5 & 4 & 34 & 1 & 0.9 \\
7 & 13 & 5 & 5 & 4 & 34 & 1 & 0.9 \\
7.5 & 12.5 & 5 & 5 & 5 & 35 & 1 & 0.9 \\
\hline & & & & & & &
\end{tabular}

Onychomys leucogaster (Table 20). What follows are notes on some of the important issues raised by these data.
TABLE 3. Pan troglodytes precaudal formulae in order of frequency $(n=179)$

\begin{tabular}{lccccc}
\hline Cervical & Thoracic & Lumbar & Sacral & $\#$ & $\%$ \\
\hline 7 & 13 & 4 & 6 & 44 & 24.6 \\
7 & 13 & 4 & 5 & 43 & 24.0 \\
7 & 13 & 3 & 6 & 29 & 16.2 \\
7 & 14 & 3 & 6 & 13 & 7.3 \\
7 & 13 & 3 & 5 & 10 & 5.6 \\
7 & 13 & 3 & 7 & 7 & 3.9 \\
7 & 13 & 3.5 & 5.5 & 6 & 3.4 \\
7 & 13 & 3 & 5 & 5 & 2.8 \\
7 & 12 & 4 & 5 & 3 & 1.7 \\
7 & 13 & 3.5 & 6.5 & 2 & 1.1 \\
7 & 13.5 & 3.5 & 6 & 2 & 1.1 \\
7 & 14 & 4 & 5 & 2 & 1.1 \\
7 & 14 & 4 & 6 & 2 & 1.1 \\
6.5 & 13.5 & 4 & 5 & 1 & 0.6 \\
7 & 12 & 3 & 6 & 1 & 0.6 \\
7 & 12 & 5 & 4 & 1 & 0.6 \\
7 & 13 & 3.5 & 6 & 1 & 0.6 \\
7 & 13 & 4 & 4 & 1 & 0.6 \\
7 & 13 & 4 & 7 & 1 & 0.6 \\
7 & 13 & 5 & 5 & 1 & 0.6 \\
7 & 13 & 5 & 6 & 1 & 0.6 \\
7 & 13.5 & 3.5 & 5 & 1 & 0.6 \\
7 & 14 & 2 & 6 & 1 & 0.6 \\
7 & 14 & 3 & 7 & 1 & 0.6 \\
\hline
\end{tabular}

\section{Patterning of intraspecific variation}

Most species show considerable variability in axial patterning, although many patterns occur at low frequencies within populations. This means that large samples are generally necessary to adequately document variability. However, in the case of Pan paniscus, a small sample $(\mathrm{n}=17)$ documents almost as many patterns (14 precaudal, 15 total) as there are individuals (Tables $5 \&$ 6). Conversely, for some cercopithecoid species, for example Trachypithecus cristatus (Table 17), even large samples $(\mathrm{n}=71)$ document only a few precaudal patterns, in this case just four, and the 882 Macaca fuscata document only 16 patterns, just two more than recorded in the 17 Pan paniscus.

There is also intraspecific variation in two parameters of interest, total number of vertebrae (documenting original number of somites) which is readily summarized for tail-less hominoids, and number of thoracic plus lumbar vertebrae (documenting separation of fore- and hindlimbs). Reliable data from large samples on the number of caudals, and hence total vertebral number, are difficult to obtain on tailed species because of curatorial problems with museum collections. The 
TABLE 4. Pan troglodytes total vertebrae formulae in order of frequency $(n=139)$

\begin{tabular}{|c|c|c|c|c|c|c|c|}
\hline Cervical & Thoracic & Lumbar & Sacral & Caudal & Total & $\#$ & $\%$ \\
\hline 7 & 13 & 4 & 6 & 3 & 33 & 21 & 15. \\
\hline 7 & 13 & 4 & 5 & 3 & 32 & 14 & 10 \\
\hline 7 & 13 & 3 & 6 & 4 & 33 & 12 & \\
\hline 7 & 13 & 4 & 6 & 2 & 32 & 9 & 6 \\
\hline 7 & 13 & 4 & 5 & 5 & 34 & 8 & \\
\hline 7 & 13 & 3 & 6 & 3 & 32 & 7 & \\
\hline 7 & 13 & 4 & 6 & 4 & 34 & 6 & \\
\hline 7 & 13 & 3.5 & 5.5 & 3 & 32 & 5 & \\
\hline 7 & 14 & 3 & 6 & 2 & 32 & 5 & \\
\hline 7 & 13 & 3 & 7 & 3 & 33 & 5 & \\
\hline 7 & 13 & 4 & 5 & 4 & 33 & 5 & \\
\hline 7 & 14 & 3 & 5 & 4 & 33 & 4 & \\
\hline 7 & 13 & 4 & 5 & 2 & 31 & 3 & \\
\hline 7 & 13 & 3 & 5 & 4 & 32 & 3 & \\
\hline 7 & 14 & 3 & 5 & 3 & 32 & 3 & \\
\hline 7 & 14 & 3 & 6 & 3 & 33 & 3 & \\
\hline 7 & 13 & 3 & 6 & 2 & 31 & 2 & \\
\hline 7 & 13 & 3 & 6 & 5 & 34 & 2 & \\
\hline 7 & 14 & 4 & 6 & 3 & 34 & 2 & \\
\hline 7 & 12 & 3 & 6 & 3 & 31 & 1 & \\
\hline 7 & 12 & 4 & 5 & 3 & 31 & 1 & \\
\hline 7 & 13 & 4 & 5 & 3 & 31 & 1 & \\
\hline 6.5 & 13.5 & 4 & 5 & 3 & 32 & 1 & \\
\hline 7 & 12 & 4 & 5 & 4 & 32 & 1 & \\
\hline 7 & 13.5 & 3.5 & 5 & 3 & 32 & 1 & \\
\hline 7 & 13 & 3.5 & 6 & 3 & 32.5 & 1 & \\
\hline 7 & 12 & 4 & 5 & 5 & 33 & 1 & \\
\hline 7 & 13 & 3 & 5 & 5 & 33 & 1 & \\
\hline 7 & 13.5 & 3.5 & 6 & 3 & 34 & 1 & 0 \\
\hline 7 & 13 & 3 & 7 & 4 & 34 & 1 & \\
\hline 7 & 13 & 3.5 & 6.5 & 4 & 34 & 1 & \\
\hline 7 & 13 & 5 & 5 & 4 & 34 & 1 & 0. \\
\hline 7 & 14 & 2 & 6 & 5 & 34 & 1 & 0 \\
\hline 7 & 14 & 3 & 6 & 4 & 34 & 1 & \\
\hline 7 & 14 & 3 & 7 & 3 & 34 & 1 & \\
\hline 7 & 14 & 3 & 5 & 5 & 34 & 1 & 0.7 \\
\hline 7 & 14 & 4 & 5 & 4 & 34 & 1 & 0 \\
\hline 7 & 13 & 4 & 6 & 5 & 35 & 1 & \\
\hline 7 & 14 & 4 & 5 & 6 & 36 & 1 & 0 \\
\hline
\end{tabular}

Schultz data on caudal number is useful for only one cercopithecoid species, Papio papio, where totals vary between 19 and 24 vertebrae for a range of six. Wilson ('72) documents four Macaca species, with ranges varying between three and seven vertebrae, while Schultz ceboid data provide ranges of three and four for two species. These ranges are comparable to the six in a very large sample (489) of the laboratory rabbit (Sawin, '37), and also to the four or five observed in the hominoids reported here. It appears that across mammals, the intraspecific variability of original somite number has a range of no more than seven, and normally fewer. In all the hominoid samples,
TABLE 5. Pan paniscus precaudal formulae in order of frequency $(n=17)$

\begin{tabular}{lcccc}
\hline Cervical & Thoracic & Lumbar & Sacral & $\%$ \\
\hline 7 & 14 & 3 & 6 & 11.8 \\
7 & & & & \\
7 & 13 & 4 & 6 & 11.8 \\
7 & 13 & 4 & 7 & 11.8 \\
7 & 13 & 4 & 5 & 5.9 \\
7 & 13 & 3 & 7 & 5.9 \\
7 & 13.5 & 3.5 & 7 & 5.9 \\
7 & 14 & 3 & 7 & 5.9 \\
7 & 14 & 4 & 6 & 5.9 \\
7.5 & 13 & 4 & 6.5 & 5.9 \\
7 & 14.5 & 4 & 5 & 5.9 \\
7 & 14 & 4 & 7 & 5.9 \\
7 & 14 & 3 & 6.5 & 5.9 \\
7 & 14 & 3 & 8 & 5.9 \\
\hline
\end{tabular}

TABLE 6. Pan paniscus total vertebrae formula in order of frequency $(n=17)$

Cervical Thoracic Lumbar Sacral Caudal Total \# \%

\begin{tabular}{lllllllr}
\hline 7 & 13 & 4 & 6 & 3 & 33 & 2 & 11.8 \\
7 & 13 & 4 & 7 & 3 & 34 & 2 & 11.8 \\
7 & 13.5 & 3.5 & 7 & 2 & 33 & 1 & 5.9 \\
7 & 14 & 4 & 7 & 2 & 34 & 1 & 5.9 \\
7 & 14 & 3 & 6.5 & 2.5 & 33 & 1 & 5.9 \\
7 & 12 & 5 & 6 & 3 & 33 & 1 & 5.9 \\
7 & 13 & 3 & 7 & 3 & 33 & 1 & 5.9 \\
7 & 14 & 3 & 6 & 3 & 33 & 1 & 5.9 \\
7 & 14 & 3 & 7 & 3 & 34 & 1 & 5.9 \\
7 & 14 & 4 & 6 & 3 & 34 & 1 & 5.9 \\
7 & 14 & 3 & 8 & 3 & 35 & 1 & 5.9 \\
7 & 13 & 4 & 6.5 & 3.5 & 34 & 1 & 5.9 \\
7 & 13 & 4 & 5 & 4 & 33 & 1 & 5.9 \\
7.5 & 14.5 & 4 & 5 & 4 & 35 & 1 & 5.9 \\
7 & 14 & 3 & 6 & 5 & 35 & 1 & 5.9 \\
\hline
\end{tabular}

two or at most three classes (numbers of vertebrae) contain a large fraction of the total variation. For example, in the Homo sapiens sample of 109 specimens (Table 2), 104 have either 33 or 34 vertebrae, while in the Pan troglodytes sample (Table 4), all but 10 of 138 specimens have 32, 33, or 34 vertebrae.

The total number of thoracic plus lumbar vertebrae also varies within species by three or four vertebrae: for example, from 16 to 18 in humans, 15 to 18 in Pan troglodytes and Gorilla g. gorilla, and 16 to 19 in Hylobates syndactylus.

At any given sample size, hominoids, and possibly ceboids, have more axial patterns than cercopithecoids and may be intrinsically more variable (Tables 1-18). The modal pattern, or 
TABLE 7. Gorilla g. gorilla precaudal formulae in order of frequency $(n=86)$

\begin{tabular}{lcccr}
\hline Cervical & Thoracic & Lumbar & Sacral & $\%$ \\
\hline 7 & 13 & 4 & 5 & 27.9 \\
7 & 13 & 4 & 6 & 23.3 \\
7 & 13 & 3 & 6 & 19.8 \\
7 & 13 & 3 & 5 & 5.8 \\
7 & 14 & 3 & 5 & 4.6 \\
7 & 14 & 3 & 6 & 3.5 \\
7 & 13 & 3 & 7 & 2.3 \\
7 & 12 & 4 & 5 & 2.3 \\
7 & 14 & 4 & 5 & 1.2 \\
7 & 12 & 4 & 6 & 1.2 \\
7 & 13.5 & 3.5 & 8 & 1.2 \\
7 & 13 & 4 & 4 & 1.2 \\
7 & 12 & 4 & 6 & 1.2 \\
7 & 13 & 3 & 6.5 & 1.2 \\
7 & 12 & 3 & 6 & 1.2 \\
6.5 & 12.5 & 4 & 6 & 1.2 \\
7 & 13 & 3.5 & 5.5 & 1.2 \\
\hline
\end{tabular}

TABLE 8. Gorilla g. gorilla total vertebra formulae in order of

\begin{tabular}{lccccccc}
\multicolumn{7}{c}{ frequency $(n=54)$} \\
\hline Cervical & Thoracic & Lumbar & Sacral & Caudal & Total & $\#$ & $\%$ \\
\hline 7 & 13 & 4 & 6 & 3 & 33 & 9 & 16.7 \\
7 & 13 & 3 & 6 & 2 & 31 & 6 & 11.1 \\
7 & 13 & 4 & 5 & 3 & 32 & 5 & 9.2 \\
7 & 13 & 4 & 5 & 2 & 31 & 4 & 7.4 \\
7 & 13 & 3 & 6 & 4 & 33 & 4 & 7.4 \\
7 & 13 & 4 & 5 & 4 & 33 & 4 & 7.4 \\
7 & 12 & 4 & 5 & 3 & 31 & 2 & 3.7 \\
7 & 13 & 4 & 5 & 5 & 34 & 2 & 3.7 \\
7 & 14 & 3 & 6 & 4 & 34 & 2 & 3.7 \\
7 & 13 & 4 & 6 & 5 & 35 & 2 & 3.7 \\
7 & 13 & 3 & 5 & 2 & 30 & 1 & 1.8 \\
7 & 13 & 3 & 5 & 3 & 31 & 1 & 1.8 \\
7 & 14 & 3 & 5 & 2 & 31 & 1 & 1.8 \\
7 & 13 & 3 & 6 & 3 & 32 & 1 & 1.8 \\
7 & 13 & 3.5 & 5.5 & 3 & 32 & 1 & 1.8 \\
7 & 13 & 4 & 4 & 4 & 32 & 1 & 1.8 \\
7 & 13 & 4 & 6 & 2 & 32 & 1 & 1.8 \\
7 & 14 & 3 & 5 & 3 & 32 & 1 & 1.8 \\
7 & 13 & 3 & 6.5 & 3.5 & 33 & 1 & 1.8 \\
7 & 13 & 3 & 7 & 3 & 33 & 1 & 1.8 \\
7 & 13.5 & 3.5 & 8 & 1 & 33 & 1 & 1.8 \\
7 & 14 & 3 & 5 & 4 & 33 & 1 & 1.8 \\
7 & 13 & 3 & 6 & 5 & 34 & 1 & 1.8 \\
7 & 13 & 4 & 6 & 4 & 34 & 1 & 1.8 \\
\hline & & & & & & \\
\hline
\end{tabular}

two most frequent patterns, comprise more of total intraspecific variation in cercopithecoids and humans than in apes and someceboids (Table 19). One way to express this patterning of variability is to compute a morphological analogue of Nei's genetic "average heterozygosity index" (Nei, '87,
TABLE 9. Gorilla g. graueri/beringei precudal formulae in order of frequency $(n=14)$

\begin{tabular}{lcccc}
\hline Cervical & Thoracic & Lumbar & Sacral & $\%$ \\
\hline 7 & 13 & 3 & 6 & 64.3 \\
7 & 12 & 4 & 6 & 14.3 \\
7 & 12 & 4 & 5 & 7.1 \\
7 & 13 & 4 & 6 & 7.1 \\
7 & 13 & 3 & 5 & 7.1 \\
\hline
\end{tabular}

TABLE 10. Pongo pygmaeus precaudal formulae in order frequency $(n=153)$

\begin{tabular}{lllll}
\hline Cervical & Thoracic & Lumbar & Sacral & $\%$ \\
\hline 7 & 12 & 4 & 5 & 37.2 \\
7 & 12 & 4 & 6 & 18.3 \\
7 & 12 & 4 & 4 & 6.2 \\
7 & 12 & 3 & 6 & 3.3 \\
7 & 11 & 4 & 6 & 3.3 \\
7 & 12 & 5 & 5 & 3.3 \\
7 & 11 & 4 & 5 & 3.3 \\
7 & 11.5 & 3.5 & 6 & 2.6 \\
7 & 11 & 5 & 5 & 2.6 \\
7 & 12 & 5 & 6 & 2.6 \\
7 & 12 & 5 & 4 & 2.0 \\
7 & 11.5 & 4.5 & 5 & 2.0 \\
7 & 12 & 3 & 5 & 1.3 \\
6 & 12 & 4 & 5 & 1.3 \\
7 & 13 & 4 & 5 & 1.3 \\
7 & 11.5 & 3.5 & 5 & 1.3 \\
6 & 13 & 4 & 6 & 1.3 \\
7 & 12 & 4 & 7 & 1.3 \\
7 & 12 & 3.5 & 5.5 & 1.3 \\
7 & 11 & 5 & 4 & 0.7 \\
7 & 12 & 4.5 & 5.5 & 0.7 \\
7 & 12.5 & 3.5 & 5 & 0.7 \\
7 & 13 & 3 & 6 & 0.7 \\
7 & 13 & 4 & 6 & 0.7 \\
6.5 & 11.5 & 5 & 5 & 0.7 \\
7 & 13 & 3 & 5 & 0.7 \\
7 & 11 & 5 & 6 & 0.7 \\
\hline & & & &
\end{tabular}

p. 177). This analogue index, which I term "morphological heterogeneity," ranges from 0 to 1 and reflects how variation is patterned. It measures the probability of sampling the same pattern in two individuals drawn at random from a population: few patterns present at high frequency with the remainder at much lower frequency yield lower index values, while variation partitioned more evenly across patterns yields higher index values. Table 21 records the indices for some representative anthropoids. Of the hominoids (the only data set for which total vertebral numbers are available), apes have higher 
TABLE 11. Pongo pygmaeus total vertebrae formulae in order of frequency $(n=131)$

\begin{tabular}{|c|c|c|c|c|c|c|c|}
\hline Cervical & Thoracic & Lumbar & Sacral & Caudal & Total & $\#$ & $\%$ \\
\hline 7 & 12 & 4 & 5 & 3 & 31 & 31 & 23.7 \\
\hline 7 & 12 & 4 & 6 & 2 & 31 & 13 & 9.9 \\
\hline 7 & 12 & 4 & 6 & 3 & 32 & 12 & 9.2 \\
\hline 7 & 12 & 4 & 5 & 2 & 30 & 11 & 8.4 \\
\hline 7 & 12 & 4 & 5 & 4 & 32 & 7 & 5.3 \\
\hline 7 & 12 & 4 & 4 & 3 & 30 & 4 & 3 \\
\hline 7 & 12 & 5 & 6 & 2 & 32 & 4 & 3 \\
\hline 7 & 12 & 3 & 6 & 2 & 30 & 3 & 2.3 \\
\hline 7 & 11.5 & 3.5 & 6 & 3 & 31 & 3 & 2.3 \\
\hline 7 & 12 & 3 & 5 & 2 & 29 & 2 & 1.5 \\
\hline 7 & 11 & 4 & 5 & 3 & 30 & 2 & 1.5 \\
\hline 7 & 11 & 4 & 6 & 2 & 30 & 2 & 1.5 \\
\hline 7 & 11 & 5 & 5 & 2 & 30 & 2 & 1.5 \\
\hline 6 & 12 & 4 & 5 & 4 & 31 & 2 & 1.5 \\
\hline 7 & 12 & 3 & 6 & 3 & 31 & 2 & 1.5 \\
\hline 7 & 12 & 3.5 & 5.5 & 3 & 31 & 2 & 1.5 \\
\hline 7 & 12 & 5 & 5 & 2 & 31 & 2 & 1.5 \\
\hline 7 & 12 & 4 & 7 & 2 & 32 & 2 & 1.5 \\
\hline 7 & 12 & 5 & 5 & 3 & 32 & 2 & 1.5 \\
\hline 7 & 11 & 4 & 5 & 2 & 29 & 1 & 0.8 \\
\hline 7 & 12 & 4 & 5 & 1 & 29 & 1 & 0.8 \\
\hline 7 & 11.5 & 3.5 & 5 & 3 & 30 & 1 & 0.8 \\
\hline 7 & 11.5 & 3.5 & 6 & 2 & 30 & 1 & 0.8 \\
\hline 7 & 11.5 & 4.5 & 5 & 2 & 30 & 1 & 0.8 \\
\hline 6 & 12 & 4 & 6 & 1 & 30 & 1 & 0.8 \\
\hline 6.5 & 13 & 4 & 6 & 2 & 31 & 1 & 0.8 \\
\hline 7 & 11.5 & 5 & 5 & 3 & 31 & 1 & 0.8 \\
\hline 7 & 11 & 4 & 5 & 4 & 31 & 1 & 0.8 \\
\hline 7 & 11 & 4 & 6 & 3 & 31 & 1 & 0.8 \\
\hline 7 & 11 & 5 & 4 & 4 & 31 & 1 & 0.8 \\
\hline 7 & 11 & 5 & 5 & 3 & 31 & 1 & 0.8 \\
\hline 7 & 11.5 & 3.5 & 5 & 4 & 31 & 1 & 0.8 \\
\hline 7 & 11.5 & 4.5 & 5 & 3 & 31 & 1 & 0.8 \\
\hline 7 & 12 & 5 & 4 & 3 & 31 & 1 & 0.8 \\
\hline 7 & 13 & 3 & 5 & 3 & 31 & 1 & 0.8 \\
\hline 7 & 11 & 4 & 6 & 4 & 32 & 1 & 0.8 \\
\hline 7 & 11 & 5 & 5 & 4 & 32 & 1 & 0.8 \\
\hline 7 & 11 & 5 & 6 & 3 & 32 & 1 & 0.8 \\
\hline 7 & 12 & 4 & 4 & 5 & 32 & 1 & 0.8 \\
\hline 7 & 12 & 4.5 & 5.5 & 3 & 32 & 1 & 0.8 \\
\hline 7 & 13 & 4 & 6 & 2 & 32 & 1 & 0.8 \\
\hline 7 & 12.5 & 3.5 & 5 & 5 & 33 & 1 & 0.8 \\
\hline
\end{tabular}

values than humans. Again, this reflects the fact that the variation in humans is concentrated in the most frequent patterns, despite the fact that the number of patterns in humans is high, as in other hominoids. Table 21 also records a second index of morphological heterogeneity, calculated for precaudal patterns. Despite being a less satisfactory metric, because it does not use all vertebrae, it allows comparison of hominoids with cercopithecoids and ceboids. The two ceboids, Saimiri sciureus and Cebus apella, despite having
TABLE 12. Hylobates lar precaudal formulae in order of frequency $(n=105)$

\begin{tabular}{lcccc}
\hline Cervical & Thoracic & Lumbar & Sacral & $\%$ \\
\hline 7 & 13 & 5 & 5 & 44.8 \\
7 & 13 & 5 & 4 & 21.0 \\
7 & 13 & 6 & 4 & 9.5 \\
7 & 13 & 6 & 5 & 4.8 \\
7 & 13.5 & 5.5 & 4 & 3.8 \\
7 & 14 & 5 & 5 & 3.8 \\
7 & 13 & 5 & 6 & 2.9 \\
7 & 14 & 5 & 4 & 2.9 \\
7 & 12 & 6 & 4 & 1.9 \\
7 & 13 & 6 & 3 & 1.9 \\
6 & 14 & 5 & 4 & 1.0 \\
6 & 13 & 6 & 4 & 1.0 \\
7 & 14 & 4 & 5 & 1.0 \\
\hline
\end{tabular}

TABLE 13. Hylobates lar total vertebrae formulae in order of frequency $(n=105)$

\begin{tabular}{lccccccc}
\hline Cervical & Thoracic & Lumbar & Sacral & Caudal & Total & $\#$ & $\%$ \\
\hline 7 & 13 & 5 & 5 & 3 & 33 & 23 & 21.9 \\
7 & 13 & 5 & 5 & 2 & 32 & 20 & 19.0 \\
7 & 13 & 5 & 4 & 3 & 32 & 12 & 11.4 \\
7 & 13 & 5 & 4 & 4 & 33 & 7 & 6.7 \\
7 & 13 & 6 & 4 & 3 & 33 & 6 & 5.7 \\
7 & 13 & 6 & 5 & 2 & 33 & 4 & 3.8 \\
7 & 13 & 6 & 4 & 2 & 32 & 3 & 2.9 \\
7 & 13 & 5 & 6 & 2 & 33 & 3 & 2.9 \\
7 & 13.5 & 5.5 & 4 & 3 & 33 & 3 & 2.9 \\
7 & 13 & 5 & 5 & 4 & 34 & 3 & 2.9 \\
7 & 13 & 5 & 4 & 2 & 31 & 2 & 1.9 \\
7 & 14 & 5 & 4 & 3 & 33 & 2 & 1.9 \\
7 & 14 & 5 & 5 & 2 & 33 & 2 & 1.9 \\
7 & 14 & 5 & 5 & 3 & 34 & 2 & 1.9 \\
7 & 13 & 5 & 5 & 1 & 31 & 1 & 1.0 \\
7 & 13 & 6 & 3 & 2 & 31 & 1 & 1.0 \\
6 & 14 & 5 & 4 & 3 & 32 & 1 & 1.0 \\
7 & 12 & 6 & 4 & 3 & 32 & 1 & 1.0 \\
7 & 13 & 6 & 3 & 3 & 32 & 1 & 1.0 \\
7 & 13 & 6 & 5 & 1 & 32 & 1 & 1.0 \\
7 & 13.5 & 5.5 & 4 & 2 & 32 & 1 & 1.0 \\
7 & 14 & 5 & 4 & 2 & 32 & 1 & 1.0 \\
6 & 13 & 6 & 4 & 4 & 33 & 1 & 1.0 \\
7 & 12 & 6 & 4 & 4 & 33 & 1 & 1.0 \\
7 & 13 & 5 & 4 & 5 & 34 & 1 & 1.0 \\
7 & 13 & 6 & 4 & 4 & 34 & 1 & 1.0 \\
7 & 14 & 4 & 5 & 4 & 34 & 1 & 1.0 \\
7 & & & & & & &
\end{tabular}

rather small sample sizes (28 and 13 respectively, Table 18) have indices falling above humans and just overlapping with the apes. Three of the four cercopithecoid species documented here have much lower indices than hominoids or ceboids. 
TABLE 14. Hylobates syndactylus precaudal formulae in order of frequency $(n=62)$

\begin{tabular}{lcccc}
\hline Cervical & Thoracic & Lumbar & Sacral & $\%$ \\
\hline 7 & 13 & 5 & 4 & 21.5 \\
7 & 13 & 4 & 5 & 21.5 \\
7 & 13 & 5 & 5 & 18.5 \\
7 & 13 & 4 & 4 & 10.8 \\
7 & 14 & 4 & 5 & 7.7 \\
7 & 14 & 4 & 4 & 4.6 \\
7 & 13 & 4 & 6 & 3.1 \\
7 & 14 & 5 & 5 & 3.1 \\
7 & 12 & 6 & 3 & 1.5 \\
8 & 12 & 5 & 5 & 1.5 \\
7 & 12 & 4 & 5 & 1.5 \\
7 & 12 & 5 & 4 & 1.5 \\
7 & 13 & 5 & 6 & 1.5 \\
7 & 12 & 5 & 5 & 1.5 \\
\hline
\end{tabular}

TABLE 15. Hylobates syndactylus total vertebrae formulae in order of frequency $(n=21)$

\begin{tabular}{lccccccc}
\hline Cervical & Thoracic & Lumbar & Sacral & Caudal & Total & $\#$ & $\%$ \\
\hline 7 & 13 & 5 & 4 & 3 & 32 & 4 & 19.0 \\
7 & 13 & 5 & 5 & 2 & 32 & 3 & 14.3 \\
7 & 13 & 5 & 4 & 2 & 31 & 2 & 9.5 \\
7 & 13 & 4 & 5 & 3 & 32 & 2 & 9.5 \\
7 & 13 & 4 & 5 & 1 & 30 & 1 & 4.8 \\
7 & 12 & 6 & 3 & 3 & 31 & 1 & 4.8 \\
7 & 13 & 4 & 5 & 2 & 31 & 1 & 4.8 \\
7 & 14 & 4 & 5 & 2 & 31 & 1 & 4.8 \\
7 & 12 & 4 & 5 & 4 & 32 & 1 & 4.8 \\
7 & 12 & 5 & 5 & 3 & 32 & 1 & 4.8 \\
7 & 13 & 4 & 4 & 4 & 32 & 1 & 4.8 \\
7 & 14 & 4 & 5 & 2 & 32 & 1 & 4.8 \\
7 & 13 & 4 & 5 & 4 & 33 & 1 & 4.8 \\
7 & 14 & 4 & 5 & 4 & 34 & 1 & 4.8 \\
\hline
\end{tabular}

These indices reflect the patterning of variation, and suggest that in some cases strong stabilizing selection concentrates most of the variation in a few formulae, generating a low index. This further suggests that cursorial quadrupedalism and bipedalism (cercopithecoids and hominins) are relatively more specialized locomotor adaptations which select for a narrower range of phenotypes. Filler ('94) reports that a fraction of human patients exhibiting chronic and severe back and lower limb pain have either four or six vertebrae, which might indicate some fitness consequences for nonmodal values. It further suggests that the suspensory postures and more generalized quadrupedalism of apes and ceboids are less specialized locomotor repertoires which tolerate a broader range of phenotypes. Of note is that the small, scansorial (and relatively less specialized) rodent Onychmys leucogaster has a higher index than humans and most cercopithecoids.

\section{Comparison of interspecific variation}

In some comparisons between species there are no shared precaudal patterns, and in most cases where patterns are shared they are few and rare. The exceptions are of interest. Tables 23 and 24 record measures of morphological similarity, calculated in a way analogous to Nei's "normalized genetic identity index" (Nei, '87, p. 220). What I call the normalized morphological similarity index has values between 0 and 1 , with 1 reflecting complete identity in precaudal patterns and 0 no shared patterns. Its value measures the extent to which patterns are shared between species, and gives added weight to shared patterns that are relatively common in both species. The index conveys no phylogenetic information, but surely contains a mixed genetic/functional similarity signal. I discuss it more in the following "phylogeny" section, where it provides significant information when mapped onto known phylogenetic relationships. Of note are the high indices for two comparisons: Pan troglodytes and Gorilla g. gorilla (.86) and Hylobates lar and Hylobates syndactylus (.50), as well as some very low indices, including zeros, for comparisons of Hylobates lar with hominoids other than Hylobates syndactylus.

\section{Homeotic and meristic change}

The phenotypic data reported here, along with what is currently known about the genetic determinants of axial patterning, provide useful insights into whether variation in numbers of vertebrae in a particular region is meristic or homeotic. Are they due to transformations of vertebral identity leading to regional boundary shifts, or are they due to loss of a segment within a region? As noted, hominoids are particularly useful sources of phenotypic intraspecific data and interspecific comparisons, because total vertebral counts can be made accurately and easily, corresponding to original somite number.

Consider, for example, the contrast between Pongo pygmaeus and Pan troglodytes. The two species differ in total numbers of vertebrae, respectively 31.0 and 32.8 (Table 16), and hence in the original number of somites generated. Total vertebral number also varies within each species. These differences obviously are meristic. But what 
TABLE 16. Comparative vertebral data for hominoid species. \# numbers of patterns reflect different sample sizes; "data from Groves ('72)

\begin{tabular}{|c|c|c|c|c|c|c|c|c|c|c|}
\hline & $\begin{array}{l}\text { Sample } \\
\text { size }\end{array}$ & $\begin{array}{c}\text { Sample } \\
\text { size incl. } \\
\text { caudals }\end{array}$ & Cervical & Thoracic & Lumbar & Sacral & Caudal & Total & $\begin{array}{c}\text { \# Precaudal } \\
\text { patterns }\end{array}$ & $\begin{array}{c}\text { \# All } \\
\text { vertebrae } \\
\text { patterns }\end{array}$ \\
\hline Homo saplens & 181 & 109 & 7 & 12.1 & 5.0 & 5.3 & 4.3 & 33.4 & 23 & 24 \\
\hline Pan troglodytes & 179 & 139 & 7 & 13.1 & 3.6 & 5.6 & 3.4 & 32.8 & 24 & 39 \\
\hline Pan paniscus & 17 & 17 & 7 & 13.5 & 3.7 & 6.4 & 3.1 & 33.7 & 14 & 15 \\
\hline $\begin{array}{l}\text { Gorilla gorilla } \\
\text { gorilla }\end{array}$ & 88 & 54 & 7 & 13.0 & 3.6 & 5.6 & 3.2 & 32.4 & 17 & 24 \\
\hline $\begin{array}{l}\text { Gorilla gorilla } \\
\quad \text { graueri/beringel }\end{array}$ & $\begin{array}{c}35 \\
\text { (14 for } \\
\text { sacral) }\end{array}$ & 6 & 7 & 12.9 & 3.3 & 5.8 & 2.7 & 31.5 & 5 & \\
\hline Pongo pygmaeus & 153 & 131 & 7 & 11.9 & 4.0 & 5.3 & 2.8 & 31.0 & 27 & 42 \\
\hline $\begin{array}{l}\text { Hylobates } \\
\quad \text { (Hylobates) lar }\end{array}$ & 105 & 105 & 7 & 13.1 & 5.2 & 4.6 & 2.8 & 32.6 & 13 & 27 \\
\hline $\begin{array}{l}\text { Hylobates } \\
\quad \text { (Symphalangus) } \\
\text { syndactylus }\end{array}$ & 66 & 21 & 7 & 13.1 & 4.5 & 4.6 & 2.7 & 31.8 & 14 & 14 \\
\hline $\begin{array}{l}\text { Hylobates (Hylobates) } \\
\quad \text { moloch }\end{array}$ & 20 & & 7 & 13.0 & 4.7 & 4.9 & $2.7^{*}$ & & 10 & \\
\hline $\begin{array}{l}\text { Hylobates (Bunopithecus) } \\
\text { hoolock }\end{array}$ & 18 & & 7 & 12.8 & 5.0 & 4.2 & $4.5^{*}$ & & 7 & \\
\hline $\begin{array}{l}\text { Hylobates (Nomascus) } \\
\text { gabriellae }\end{array}$ & 11 & & 7 & 14.0 & 4.8 & 5.0 & & & 3 & \\
\hline $\begin{array}{l}\text { Hylobates (Nomascus) } \\
\text { concolor }\end{array}$ & 17 & & 7 & 12.9 & 4.9 & 4.4 & $3.1^{*}$ & & 6 & \\
\hline
\end{tabular}

TABLE 17. Mean vertebral numbers for precaudal regions in Cercopithecoidea

\begin{tabular}{|c|c|c|c|c|c|c|}
\hline & Sample size & Cervical & Thoracic & Lumbar & Sacral & \# patterns \\
\hline Nasalis larvatus & 34 & 7 & 12.1 & 6.9 & 3.0 & 3 \\
\hline Trachypithecus cristatus & 71 & 7 & 12.0 & 7.0 & 2.9 & 4 \\
\hline Trachypithecus phayrei & 19 & 7 & 12.1 & 7.0 & 2.9 & 5 \\
\hline Macaca fuscata & 882 & 7 & 12.2 & 6.9 & 3.1 & 16 \\
\hline Macaca fascicularis $A$ & 54 & 7 & 12.0 & 6.9 & 2.9 & 6 \\
\hline Macaca fascicularis $B$ & 25 & 7 & 12.0 & 6.9 & 2.6 & 4 \\
\hline Macaca rhesus & 16 & 7 & 12.1 & 6.9 & 3.0 & 3 \\
\hline Macaca arctoides & 23 & 7 & 12.0 & 7.0 & 3.7 & 3 \\
\hline Papio papio & 13 & 7 & 12.3 & 6.6 & 3.2 & 4 \\
\hline Lophocebus albigena & 77 & 7 & 13.0 & 6.0 & 3.0 & 7 \\
\hline Cercocebus atys & 11 & 7 & 12.4 & 6.5 & 2.9 & 6 \\
\hline Cercopithecus mitis & 16 & 7 & 12.2 & 6.8 & 2.9 & 4 \\
\hline Cercopithecus ascanius & 72 & 7 & 12.5 & 6.6 & 2.9 & 11 \\
\hline Chlorocebus aethiops & 44 & 7 & 12.1 & 6.8 & 3.0 & 7 \\
\hline Erythrocebus patas & 17 & 7 & 12.1 & 6.9 & 3.0 & 3 \\
\hline
\end{tabular}

about the difference in numbers of vertebrae within a region, again both between and within species? For example, the modal thoracic number is 12 in Pongo pygmaeus and 13 in Pan troglodytes. And within each species thoracic number varies, from 11 to 13 in Pongo and from 12 and 14 in Pan troglodytes. Are these variations meristic or homeotic? Has a vertebra (somite) been "lost" or "gained," or have vertebral identities been altered?

We know enough about the developmental genetics of the axial skeleton to be able to say that the determination of somite number and the specification of vertebral identity involve separate but overlapping genetic systems. If determination of segment number and segment identity were 


\section{PILBEAM}

TABLE 18. Mean vertebral numbers for precaudal regions in Ceboldea

\begin{tabular}{|c|c|c|c|c|c|c|}
\hline & Sample size & Cervical & Thoracic & Lumbar & Sacral & \# patterns \\
\hline Saimiri sciureus & 28 & 7 & 13.0 & 6.7 & 2.9 & 11 \\
\hline Cebus capucinus & 12 & 7 & 13.8 & 6.0 & 3.0 & 4 \\
\hline Cebus malitiosus & 7 & 7 & 13.9 & 5.1 & 3.0 & 4 \\
\hline Cebus apella & 13 & 7 & 14.0 & 5.2 & 2.8 & 7 \\
\hline Cebus albifrons & 18 & 7 & 14.0 & 5.6 & 3.0 & 7 \\
\hline Lagothrix lagotricha & 12 & 7 & 13.9 & 4.1 & 3.4 & 6 \\
\hline Ateles geoffroyi & 13 & 7 & 14.0 & 4.0 & 3.1 & 3 \\
\hline
\end{tabular}

TABLE 19. Percentage of variants in first two most frequent axial formulae classes

\begin{tabular}{|c|c|c|c|c|}
\hline Species & $\mathrm{N}$ & $1^{\text {st }}$ & 2nd & $1 \mathrm{st}+2^{\text {nd }}$ \\
\hline Homo sapiens (Japanese) & 181 & 57.5 & 22.1 & 79.6 \\
\hline Pan trogiodytes & 180 & 24.4 & 23.9 & 48.3 \\
\hline Pan paniscus & 17 & 11.8 & 11.8 & 23.6 \\
\hline Gorilla g. gorilla & 86 & 27.9 & 23.3 & 51.2 \\
\hline Gorilla g. graueri/beringel & 14 & 64.3 & 14.3 & 78.6 \\
\hline Pongo pygmaeus & 153 & 37.2 & 18.3 & 55.5 \\
\hline Hylobates lar & 105 & 44.8 & 21.0 & 65.8 \\
\hline Hylobates syndactylus & 66 & 21.5 & 21.5 & 43.0 \\
\hline Hylobates moloch & 20 & 35.0 & 15.0 & 50.0 \\
\hline Hylobates hoolock & 18 & 55.6 & 11.1 & 66.7 \\
\hline Hylobates gabriellae & 11 & 72.7 & 18.2 & 90.9 \\
\hline Hylobates concoior & 17 & 58.8 & 17.6 & 76.4 \\
\hline Nasalls larvatus & 34 & 91.1 & 5.9 & 97.1 \\
\hline Trachypithecus cristatus & 71 & 80.3 & 12.7 & 93.0 \\
\hline Trachypithecus phayrel & 19 & 78.9 & 5.3 & 84.2 \\
\hline Macaca fuscata & 882 & 70.6 & 9.8 & 80.4 \\
\hline Macaca fascicularis $A$ & 54 & 77.8 & 11.1 & 88.9 \\
\hline Macaca fascicularis $B$ & 25 & 56.0 & 36.0 & 92.0 \\
\hline Macaca rhesus & 16 & 87.5 & 6.2 & 93.8 \\
\hline Macaca arctoides & 23 & 65.2 & 30.4 & 95.6 \\
\hline Papio papio & 13 & 53.8 & 30.8 & 84.6 \\
\hline Lophocebus albigena & 77 & 88.3 & 5.2 & 93.5 \\
\hline Cercocebus atys & 11 & 36.4 & 27.3 & 63.7 \\
\hline Cercopithecus mitis & 16 & 68.8 & 18.8 & 87.6 \\
\hline Cercopithecus ascanius & 72 & 34.7 & 27.8 & 62.5 \\
\hline Chlorocebus aethiops & 44 & 70.4 & 9.1 & 79.5 \\
\hline Erythrocebus patas & 17 & 88.2 & 5.9 & 94.1 \\
\hline Saimiri sciureus & 28 & 39.2 & 14.3 & 53.5 \\
\hline Cebus capucinus & 12 & 66.7 & 16.7 & 83.4 \\
\hline Cebus malltiosus & 7 & 57.0 & 14.0 & 71.0 \\
\hline Cebus apella & 13 & 53.8 & 7.7 & 61.5 \\
\hline Cebus albifrons & 18 & 38.8 & 22.2 & 61.0 \\
\hline Lagothrix lagotricha & 12 & 41.7 & 16.7 & 58.4 \\
\hline Ateles geoffroyi & 13 & 84.6 & 7.7 & 92.3 \\
\hline Onychomys leucogaster & 71 & 53.5 & 15.5 & 69.0 \\
\hline Sciureus caroiensis & 51 & 88.0 & 4.0 & 92.0 \\
\hline Microsciureus alfari & 14 & 92.1 & 7.1 & 100.0 \\
\hline Microsciureus mimulus & 12 & 83.3 & 8.3 & 91.7 \\
\hline Microsciureus flaviventer & 15 & 80.0 & 20.0 & 100.0 \\
\hline
\end{tabular}


under completely separate genetic control, vertebral specification would proceed with no regard to total vertebral numbers. Because axial identity is determined during development in a cranial to caudal direction, we could hypothesize that vertebral determination might be unrelated to total vertebral number within a species. Caudal length would then reflect what remains after specification of other regions is completed, and this specification would be constant across individuals. Hence, differences in total vertebral numbers would not affect regional vertebral numbers or regional boundaries. Because we have a good phenotypic data set for several hominoid species, it is possible to ask the question: within a species, how much variation in total vertebral number is due to variation in just the caudal region?

We can address the question by computing, for any species, the average number of vertebrae in each vertebral region across classes defined by total vertebral number, and then noting how regional vertebral number varies as total vertebral number varies. Five of the hominoids reported

TABLE 20. Onychomys leucogaster precaudal formulae in order of frequency $(n=71)$

\begin{tabular}{lcccr}
\hline Cervical & Thoracic & Lumbar & Sacral & $\%$ \\
\hline 7 & 13 & 6 & 3 & 53.5 \\
7 & 13 & 6 & 4 & 15.5 \\
7 & 13 & 6 & 2 & 15.5 \\
7 & 13 & 6 & 4 & 4.2 \\
7 & 12 & 7 & 2 & 2.8 \\
7 & 13 & 5.5 & 3.5 & 2.8 \\
7 & 13 & 5.5 & 2.5 & 1.4 \\
7 & 13 & 7 & 2 & 1.4 \\
7 & 12 & 7 & 3 & 1.4 \\
7 & 13 & 6 & 3.5 & 1.4 \\
7 & 14 & 5 & 4 & 1.4 \\
7 & 13 & 5 & 3 & 1.4 \\
\hline
\end{tabular}

TABLE 22. Morphological heterogeneity indices

\begin{tabular}{lcc}
\hline & $\begin{array}{c}\text { Total } \\
\text { vertebrae }\end{array}$ & $\begin{array}{c}\text { Precaudal } \\
\text { vertebrae }\end{array}$ \\
\hline Homo sapiens & 0.789 & 0.619 \\
Pan troglodytes & 0.944 & 0.843 \\
Gorilla g. gorilla & 0.933 & 0.821 \\
Pan paniscus & 0.933 & 0.922 \\
Pongo pygmaeus & 0.914 & 0.818 \\
Hylobates lar & 0.891 & 0.740 \\
Hylobates syndactylus & 0.906 & 0.853 \\
Macaca fuscata & & 0.482 \\
Lophocebus albigena & & 0.217 \\
Trachypithecus cristatus & & 0.336 \\
Cercoplthecus ascanius & & 0.776 \\
Saimiri sciureus & & 0.794 \\
Cebus apella & & 0.676 \\
Onychomys leucogaster & & 0.661 \\
\hline
\end{tabular}

TABLE 23. Morphological similarity indices

\begin{tabular}{ll}
\hline Homo sapiens/Pan troglodytes & 0.02 \\
Pan troglodytes/Gorilla g. gorilla & 0.86 \\
Hylobates lar/Hyiobatos syndactylus & 0.50 \\
Homo saplens/Pongo pygmaeus & 0.001 \\
Ran troglodytes/Pongo pygmaeus & 0.04 \\
Pan troglodytes/Hylobates syndactylus & 0.18 \\
Pan troglodytes/Pan paniscus & 0.39 \\
Homo sapiens/Pan paniscus & 0.02 \\
Homo sapiens/Gorilla g. gorilla & 0.02 \\
Pan paniscus/Gorilla g. gorilla & 0.37 \\
Homo sapiens/Hylobates lar & 0.0006 \\
Pongo pygmaeus/Hylobates syndactylus & 0.004 \\
Homo sapiens/Hylobates syndactylus & 0.009 \\
Pan troglodytes/Hylobates lar & 0.003 \\
Pan paniscus/Hylobates syndactylus & 0.038 \\
Gorilla g. gorilla/Pongo pygmaeus & 0.118 \\
Gorilla g. gorilla/Hylobates syndactylus & 0.164 \\
Pan paniscus/Pongo pygmaeus & 0 \\
Pan paniscus/Hylobates lar & 0 \\
Gorilla g. gorilla/Hylobates lar & 0 \\
\hline
\end{tabular}

TABLE 21. Comparison of first nine most frequent axial formulae in Pan troglodytes and Gorilla g. gorilla

\begin{tabular}{|c|c|c|c|c|c|c|c|c|c|c|c|}
\hline \multirow{3}{*}{$\frac{\text { Rank }}{1}$} & \multicolumn{4}{|c|}{ Pan troglodytes $(\mathrm{n}=179)$} & \multicolumn{5}{|c|}{ Gorilla g. gorilla $(\mathrm{n}=86)$} & \multirow[b]{2}{*}{$\%$} & \multirow[b]{2}{*}{ Chimp rank } \\
\hline & & & Pattern & & $\%$ & & & Pattern & & & \\
\hline & 7 & 13 & 4 & 6 & 24.6 & 7 & 13 & 4 & 5 & 27.9 & 2 \\
\hline 2 & 7 & 13 & 4 & 5 & 24.0 & 7 & 13 & 4 & 6 & 23.3 & 1 \\
\hline 3 & 7 & 13 & 3 & 6 & 16.2 & 7 & 13 & 3 & 6 & 19.8 & 3 \\
\hline 4 & 7 & 14 & 3 & 6 & 7.3 & 7 & 13 & 3 & 5 & 5.8 & 8 \\
\hline 5 & 7 & 14 & 3 & 5 & 5.6 & 7 & 14 & 3 & 5 & 4.6 & 5 \\
\hline 6 & 7 & 13 & 3 & 7 & 3.9 & 7 & 14 & 3 & 6 & 3.5 & 4 \\
\hline 7 & 7 & 13 & 3.5 & 5.5 & 3.4 & 7 & 13 & 3 & 7 & 2.3 & 6 \\
\hline 8 & 7 & 13 & 3 & 5 & 2.8 & 7 & 12 & 4 & 5 & 2.3 & 9 \\
\hline 9 & 7 & 12 & 4 & 5 & 1.7 & 7 & 13 & 3.5 & 5.5 & 1.2 & 7 \\
\hline
\end{tabular}


TABLE 24. Matrix of morphological similarity indices

\begin{tabular}{|c|c|c|c|c|c|c|c|}
\hline & H.s. & P.t. & P.p. & G.g.g. & Po.pyg. & Hy.l. & Hy.s. \\
\hline Homo sapiens & $\mathrm{x}$ & 0.02 & 0.02 & 0.02 & 0.001 & 0.0006 & 0.009 \\
\hline Pan troglodytes & & $\mathrm{x}$ & 0.3 & 0.86 & 0.04 & 0.003 & 0.18 \\
\hline Pan paniscus & & & $\mathrm{x}$ & 0.37 & 0 & 0 & 0.04 \\
\hline Gorilla g. gorilla & & & & $\mathrm{x}$ & 0.12 & 0 & 0.16 \\
\hline Pongo pygmaeus & & & & & $\mathrm{x}$ & 0 & 0.04 \\
\hline Hylobates lar & & & & & & $\mathrm{x}$ & 0.50 \\
\hline Hylobates syndactylus & & & & & & & $\mathrm{x}$ \\
\hline
\end{tabular}

here have adequate samples: Homo sapiens (109), Pan troglodytes (139), Gorilla g. gorilla (54), Pongo pygmaeus (131), and Hylobates lar (105). Analysis shows that, as total number of vertebrae within a species increases, the caudal region contributes the most to increased total vertebral number, the percentage contribution ranging from a low of 46 in Pongo pygmaeus to a high of 78 in Pan troglodytes. The sacral region provides the second largest contribution, and together the sacral and caudal regions account for between $74 \%$ (Pongo pygmaeus) and 91\% (Homo sapiens). There is only modest variation in thoracic or lumbar numbers with increasing total vertebral number.

The same data can be analyzed in a second and complementary way. For Pan troglodytes, the first eight precaudal patterns account for about $88 \%$ of total variability. Addressing first the thoracic region, most individuals have $\mathrm{T} 13$, but around $13 \%$ have T14. But the mean number of total vertebrae does not vary between those with T13 and those with T14. For the lumbar region, a little over half are L4 and a little under half are L3. Once again, the mean number of total vertebrae does not vary between those with L4 and those with L3. This strongly implies that the variation is homeotic, due to shifts in vertebral identity rather thanloss or gain of vertebrae within a region.

For Pongo pygmaeus data are a little less clear cut. Total vertebral number is 31.0 (contrasting with 32.8 in Pan troglodytes). The twelve most frequent precaudal patterns account for about $87 \%$ of total variability. Most of these have T12, and about $14 \%$ have $\mathrm{T} 11$ or T11.5. Of those with $\mathrm{T} 12$, total vertebrae average 31.0 , while for those with T11 or 11.5 , total vertebrae average 30.6. Modal number of lumbars is 4 , but about $12 \%$ have L5 or L4.5. For T4's, total vertebrae average 30.9, while for T5/4.5's the average is 31.2. These small average differences suggestthat the majority of variation is homeotic. Similar analyses with the Homo sapiens sample show clearly that the more limited amount of variation (relative to the apes) is homeotic.

Slight shifts in the timing of gene expression and not the gain or loss of regional vertebrae best explain these data, with Hox genes being the primary but not the only suspects; the variation is probably homeotic. What does this say about homologies of vertebrae within- or between-species (Sanders and Bodenbender, '94)? Given what we know of how vertebrae are specified, and of the relationships between vertebral identity and gene expression across species, it would probably be best to homologise first lumbars with first lumbars, regardless of vertebral position, between as well as within species.

As a final comment, the concepts of homeotic and meristic change were formulated long before the genetic mechanisms of somitogenesis and vertebral specification were well understood. Given the complementary and linked nature of the two processes, it is not surprising that it is difficult to infer the relative contributions of homeotic and meristic change when explaining inter- and intraspecific variation in vertebrates such as the hominoids. Given what we now know, these are probably not particularly useful concepts when we are discussing primate axial evolution.

\section{PHYLOGENETIC HYPOTHESES}

What follows is a brief discussion of axial pattern evolution in anthropoid primates (New World Monkeys, Old World Monkeys, and hominoids). It includes hypotheses about ancestral patterns reflecting robust phylogenetic relationships, possible selective factors responsible for shaping interspecific change, and possible genetic underpinnings of these phenotypic shifts. The phylogenetic relationships of the primates discussed here are now well established (Fig. 1), primarily based on genetic data, and certainly well enough to speculate plausibly about ancestral 
vertebral patterns (Ruvolo, '97a; Goodman et al., '98; Chen and Li, 2001). Much of what follows is based on inferences from living species, there being precious few fossils complete enough to be useful in reconstruction or hypothesis testing. I will use modal values in discussing hypothetical ancestral axial formulae as a convenient way of recording the most common pattern, but emphasize nonetheless that this shorthand cannot capture the extent of the intraspecific variation which must always have existed. Indeed it is essential never to forget polymorphism in axial patterning.

Unfortunately, there are no relevant fossil specimens to aid in reconstructing the stem anthropoid axial patterns. Assuming the anthropoid common ancestor was an active pronograde arboreal quadruped, and reviewing the broad range of extant anthropoid axial patterns listed here and summarized more fully in Schultz ('61), I hypothesize that the ancestor was characterized by a precaudal modal formula of $7: 13$ or $14: 6$ or $7: 3$, with a tail. I further hypothesize that stem catarrhines were 7 :mostly $13: 6$ or $7: 3$, also with a tail. Combinations compatible with these modes are found in remains of the Middle Miocene probable stem catarrhine Pliopithecus (with tail) (Zapfe, '60). One specimen of the Early Miocene probable stem hominoid Proconsul is believed to have had six lumbars, and, based on a sacral fragment, probably lacked a tail (no sacrum is known well enough to determine number of elements) (Ward et al., '91; Ward, '93). The probably pronograde Middle Miocene hominoid Nacholapithecus also had six lumbars and at least two caudal thoracic vertebrae with lumbar-type articulations (Ishida et al., 2004), and apparently lacked a tail (Rose et al., '96; Nakatsukasa et al., 2003). These fossils (Fig. 1) suggest little average change from the inferred stem anthropoid patterns.

Cercopithecoid monkeys show less variation within and between species than do hominoids and perhaps ceboids; their most frequent patterns, particularly the modal, are present normally at very high frequencies suggesting strong selection favoring the modal pattern (Tables 19 and 22). Many have a modal axial formula of $7: 12: 7: 3$, with variable caudal number (Table 17). This suggests, relative to a hypothetical ancestral profile, a homeotic shift at the thoracolumbar boundary, with a posterior transposition of the 20 th vertebra from thoracic to lumbar. The position of the transitional vertebra also shifted craniad so that the two or three most caudal thoracic vertebrae have both ribs and lumbar-type zygapophyses. Note that I hypothesize a catarrhine common ancestor different from cercopithecoids in having 13 rather than 12 thoracic vertebrae. Cercopithecoids are surely the outgroup to hominoids, but this does not mean that we should assume that they are plesiomorphic in these features. An hypothesis that the Old World Monkey axial skeleton, along with many other features, is derived, is more plausible given the distribution of patterns in hominoids and ceboids.

Such a modest transpositional change is easily effected by slight shifts in timing of gene expression, particularly the Hox-8 and -9 paralogues. Saimiri sciureus is a small and active arboreal quadrupedal ceboid species which can be hypothesized to resemble the anthropoid and catarrhine common ancestral axial pattern profile. Of the Saimiri sample summarized here in Tables 18 and 19, 3.6\% have an axial formula characteristic of most cercopithecoids: the raw material for natural selection was there. Selection would have favored variants making active cursoriality more efficient.

Reconstructing ancestral hominoid patterns is an interesting exercise. Hominoid phylogenetics has long been dominated by the hypotheses either that great apes are monophyletic, or that Pan and Gorilla are sister taxa, closer to each other than either are to humans. As for the evolution of the vertebral column, based in part on these hypotheses, hylobatids were frequently seen as representing the prehominin axial pattern, having five lumbars (although 13 thoracics) rather than the three or four characteristic of the great apes (Filler, '93; Latimer and Ward, '93; Haeusler et al., 2002). Filler ('93, p. 17) illustrates this position well: "....my conclusion has been that length of the lumbar region has never been reduced in the lineage of upright bipedal walkers that stretch from near the dawn of the hominoid superfamily [i.e., represented by Hylobates lar: my insert] directly to modern Homo.....The common ancestor of humans and of the African apes, thus, apparently had a lumbar spine like ours..." Such assertions, which derive humans from hypothetical ancestors with five lumbars, rather than the four or three of the great apes, reflect the belief that a lumbar vertebra has been "lost" in the derivation of the great apes, and could not be "regained" were they ancestral to humans. As we have seen, such thinking is not consonant with the realities of axial development in which homeotic 
rather than meristic change is a more likely explanation for intra- and interspecific variation.

It is now abundantly clear from genetic data that humans and chimpanzees are sister taxa, with gorillas, orangutans, and gibbons successively more distantly related (Ruvolo, '97a; Chen and $\mathrm{Li}, 2001$; Pilbeam, 2002). These relationships must influence ancestral reconstructions (Fig. 1). Indeed, it is surprising, even depressing, to see in a paper published in a major journal as recently as 2002 , that an incorrect phylogeny is still used in hypothesizing ancestral hominoid axial patterns (Haeusler et al., 2002).

The phylogenetic positions of the Late Miocene apes Oreopithecus bambolii and Dryopithecus laeitanus are unclear (Fig. 1), but they both show orthograde adaptations, and in their lumbar regions were more similar to those of crown hominoids than to earlier taxa such as Proconsul and Nacholapithecus (Moyà-Solà and Köhler, '96; Haeusler et al., 2002).

For crown hominoids, I begin with the common ancestor of Pan and Gorilla. Table 21 summarizes the nine most frequent precaudal axial patterns in a large sample of Pan troglodytes (Table 3) and compares them to the nine most frequent patterns in the sample of western or lowland gorilla, G. gorilla gorilla (Table 5). The same patterns are present in each, and the three most frequent patterns in each are the same. Considering total vertebrae patterns, Tables 23 and 24 record morphological similarity indices and show that Pan troglodytes and Gorilla g. gorilla are by far the most similar hominoids. Total numbers of vertebrae are also very similar in the two species, respectively 32.8 and 32.4 (Table 10). A plausible hypothesis is that their common ancestor (presumably chimp-sized) would have had an axial pattern profile very similar to that of the living chimpanzee. The bonobo, Pan paniscus, and the eastern gorillas, G. gorilla graueri and beringei, are represented here by inadequate samples, but what is available (Tables 5, 6, 9, and 16) suggests interesting modifications from the hypothesized ancestral profile. For example (Table 16) total numbers of vertebrae are increased in bonobos (by about 1 vertebra) and decreased in the eastern gorillas (also by about one vertebra). Bonobos in particular are characterized by a quite extraordinary degree of polymorphism-14 precaudal and 15 all vertebrae patterns in a sample of just 17 animals. Tables 23 and 24 suggest that Pan paniscus is about equally similar to Pan troglodytes and Gorilla g. gorilla, and is derived from an ancestor with their common profile. I further assume that the common ancestor of hominins and Pan also resembled Pan troglodytes, given the derived nature of the hominin bipedally adapted postcranium.

The orangutan (Figure 1), Pongo pygmaeus, differs from the other apes in having an average of 12 rather than 13 thoracic vertebrae, but roughly the same number of lumbars plus sacrals as Pan troglodytes and the lowland gorilla. Total number of vertebrae is around two segments less than in Pan troglodytes. Tables 23 and 24 show low to very low similarity index values for comparisons between Pongo and other hominoids. Selection has favored in Pongo a shorter thoracic plus lumbar region (15.9 vs 16.6 or 16.7 vertebrae, Table 10$)$, achieved through reducing the number of ribbearing vertebrae from around 13 to around 12 (Table 10). (This may be because of selection for greater truncal stability given a high degree of arboreality at large body size.) The orangutan modal precaudal pattern $(7: 12: 4: 5)$, which is found in $37.2 \%$ of the sample (Table 11), is present in $1.7 \%$ of Pan troglodytes (Table 3) and $2.3 \%$ of G. gorilla gorilla (Table 7). If the common ancestor of all the great apes resembled the African apes in axial pattern profile, selection in the orangutan lineage had at least some precaudal variants on which to act. In addition, the 7:13:4:6 precaudal pattern (most frequent in Pan troglodytes and second most frequent in G. gorilla gorilla) is found in Pongo, although at very low frequency $(0.7 \%)$. As discussed earlier, I hypothesize that the shorter thoracic region in Pongo relative to the African apes reflects homeotic rather than meristic change, and was achieved as part of an overall reduction in total vertebral number.

The first of the extant hominoids to diverge (Fig. 1), the hylobatids, form an interesting group: an adaptive radiation of around a dozen mostly allopatric species of small to very small, highly arboreal, acrobatic, suspensory, orthograde apes which began its radiation in the late Miocene and hence is of similar time depth to the radiation of the African hominoid clade, Pan, Gorilla, and Homo. Four Hylobates subspecies are normally recognized. The best known and most widely cited species is Hylobates (Hylobates) lar, particularly the subspecies $H$. lar carpenteri (7:13:5:5, Table $13)$, but there is an interesting range of variation across subgenera and species which shows that using $H$. lar carpenteri as an exemplar for all hylobatids is limiting (see Table 10). Except for (Nomascus), 13 thoracics are modal, 5 is generally 
modal for lumbars but a significant fraction in some species have 4 lumbars (in Symphalangus $50 \%$ and in $H$. moloch $30 \%$ ), sacrals mainly 4 or 5 . Total somite number is 32 or 33 , comparable to the African apes and humans. The two largest samples available to me, Hylobates (Hylobates) lar and $H$. (Symphalangus) syndactylus, have a similarity index of .50 (Tables 23 and 24), the second highest value for inter-hominoid comparisons.

Two points are worth making here. First, it is a reasonable hypothesis that stem hylobatids were larger than the living species (e.g., Pilbeam, '96). Among extant hylobatids, the largest, the siamang H. (Symphalangus) syndactylus has the most reduced lumbar region (Table 10), and I hypothesize that stem hylobatids, if larger bodied, had a modal number of lumbars closer to four than five. Note that Tables 23 and 24 show that the sample of the smaller, lar gibbon has effectively no similarity to other hominoids, including Homo sapiens! In contrast, the siamang shows modest similarity values when compared to Pan troglodytes and Gorilla g. gorilla. I further hypothesize that the common ancestor of crown hominoids would have had a modal precaudal axial pattern of $7: 13: 4-5: 4-5$, and that the common ancestral precaudal pattern of hominids (great apes plus humans), 7:13:4-3:6-5, evolved through a transposition at the lumbar-sacral boundary. With the exception of the probably derived Pongo, total vertebral numbers average around 32 or 33 in hominoids.

Second, considering the data available to me on nine hylobatid populations representing six species and all four subgenera (not all summarized here, but available on request), there are 34 precaudal axial patterns recorded overall in the genus Hylobates. In many cases patterns present in some species are absent in others. For example, $7: 13: 4: 5$, the (jointly equal) precaudal modal pattern in the siamang (Table 15) is entirely absent in the large lar gibbon sample (Table 13) as well as in $H$. (Nomascus) gabriellae (data not shown). In fact, 21 of the 34 patterns are not represented in the lar sample, and 20 of the 34 are absent from the siamang sample. These examples make the point that closely related species do not have identical or even close to identical axial formulae profiles, and that not all patterns in a group of related species are necessarily found in all members of the group (important points to remember when considering variation in the African apes, humans, and fossil hominins).
Turning now to hominins, I have already hypothesized that the pre-hominin profile resembled that of Pan troglodytes (Table 3) with $7: 13: 4: 6,7: 13: 4: 5$, and 7:13:3:6 being the most common precaudal patterns. Living humans (Table 1) have a modal formula of 7:12:5:5, which pattern reaches high frequencies in all populations. When total vertebral numbers are considered (Table 10) humans (33.2) are similar to Pan troglodytes (32.8), a difference less than that between lar gibbons (32.6) and siamangs (31.8). These two taxon pairs are about equally different genetically and are therefore similar in time depth (Todaro, '80). Although values of the similarity index (Tables 23 and 24) are low for human comparisons, they are highest with Pan troglodytes and Gorilla g. gorilla, which are in turn twice (vs. siamang) to an order of magnitude or more (orangutan, lar gibbon) greater than in other hominoids.

The human modal pattern of 7:12:5:5 is present in several Late Pleistocene neandertals (Fig. 1). In his classic monograph on the human sacrum, Paterson (1893, p. 128-129) notes: "It is well known that the first sacral vertebra shows frequent signs of separation from the rest of the mass," and further records that in a sample of over two hundred sacra, more than half showed partial or total separation of first and second sacral bodies (see also Barnes, '94). Three of the four complete Late Pleistocene neandertal sacra (Shanidar 3, Ferrassie 1, and Kebara 2) also show only partial fusion of $\mathrm{S} 1$ and $\mathrm{S} 2$ (Trinkaus, '83, Figure 36; Duday and Arensburg, '91, Figure 6). Further, Duday and Ahrensburg ('91, Figure 8) note that in the Kebara 2 neandertal (Arensburg, '91) there is a second promontory between $\mathrm{S} 1$ and $\mathrm{S} 2$ in addition to that between L5 and S1, and remark ('91, page 185): "Sans que l'on puisse véritablement parler de lombalisation de S1, il est clair que tous les caractères que nous avons évoqués plaident en faveur d'une mauvaise intégration de cette vertèbre à l'étage sacré." Finally, the Middle Pleistocene pelvis of an early neandertal (ca 400-500 Ka) from Atapuerca $\mathrm{SH}$ shows apparently incomplete fusion of S1 and S2 (Arsuega et al., '99; Bermúdez de Castro et al., 2003). Taken together, these later (post ca $500 \mathrm{Ka}$ ) hominins suggest that there has been a posterior transposition, and that an ancestral sixth lumbar has been incompletely integrated into the sacrum.

The Nariokotome Homo erectus axial skeleton (Fig. 1), dated at $1.53 \mathrm{Ma}$ (Brown and McDougall, 
'93) and well described by Walker and Leakey ('93) and Latimer and Ward ('93), is the next oldest hominin preserving sufficient axial material. The last cervical and eight of the thoracic vertebrae are represented (interpreted as T1, 2, 3, 5, 7, 8, 10, 11) for an inferred total of 12 thoracics, along with six lumbars and five sacrals, the last of which resembles a coccygeal vertebra and was originally interpreted as such (Walker and Leakey, '93, Figure 7.85; Walker and Ruff, '93, Figures 10:3, 10:4). By Schultz criteria ('61, page 4, Figures 5, 12,21 ) the sacrum (albeit heavily reconstructed) would be scored as having four vertebrae, and in comparison with the Late Pleistocene sacra discussed above which have five sacral elements, this earlier hominin had either fewer vertebrae or less markedly sacralized fifth sacrals. However, the sacral vertebrae are poorly preserved and cannot be interpreted with total confidence. It also appears from illustrations of the younger (ca 400-500 Ka) Atapuerca SH sacrum (Arsuega et al., '99) on the Atapuerca locality website (http://www.ucm.es/info/paleo/ata/english/sites/ysima/skeleton.htm) that the most caudal sacral vertebrae are poorly sacralized. The Homo sapiens sample reported here (Tables $1 \& 2$ ) records the precaudal variants $7: 12: 6: 5$ and $7: 12: 6: 4$ at $2.8 \%$ frequency. (Note that the same sample records 7:13:4:5, the modal Pan troglodytes precaudal pattern, also at $2.8 \%$ frequency.) It should be noted that Haeusler et al. (2002) have examined the Nariokotome specimen and concluded that only five lumbars were present.

The oldest reasonably complete hominin axial series are those of two specimens of Australopithecus africanus (Fig. 1) from the Pliocene locality of Sterkfontein, South Africa, biochronologically dated around 2.6 to $2.8 \mathrm{Ma}$ (Robinson, '72; Sanders, '98). Sts 14 (Robinson, '72) preserves the last nine thoracics, interpreted by Sanders as T4-T12 but more conservatively by Robinson ('72, page 102) as either T4-T12 or (in my opinion less probably) T5T13. There are six lumbars defined traditionally and functionally (zygapophyseal configuration). The first lumbar has a small detached transverse process on the right side which Robinson believed was not a functional rib but rather a partially costalized lumbar transverse process ('72, p. 103); this would be described as a lumbar vertebra using the Schultz ('61, page 4) criteria. Haeusler et al. (2002) interpret this process as a rib, in which case 5.5 traditionally defined lumbars would be scored. Only parts of sacrals 1 and 2 are preserved. What is clear is that there are six presacral vertebrae with lumbar-type articulations. This pattern is present in a minority of humans, varying across populations at frequencies from zero to $40 \%$ (Allbrook, '55). Sanders ('98, page 251) notes that the incompletely described Stw-431 skeleton (McHenry and Berger, '96) also has the last four thoracics (interpreted by Sanders as T9-T12), six lumbars, and a partial sacrum, although again Haeusler et al. (2002) disagree and infer only five lumbars.

The only complete and described australopithecine sacrum is from Australopithecus afarensis, AL 288-1an, dated to 3.2 Ma (Kimbel et al., '94) and described as having five elements (Johanson et al., '82, Figures 9B, 10B). The fifth sacral vertebra is very small, lacks a left sacral foramen and may have lacked a right. According to Schultz ('61, page 4, Figures 5, 12, 21) or Paterson (1893, PlateXVII) criteria, this would be scored as a sacrum with four or at most 4.5 vertebrae. Morphologically it resembles that of the heavily reconstructed Nariokotome Homo erectus sacrum. Regardless of how these sacra are scored for vertebral number, relative to Late Pleistocene hominin and living human sacra the more caudad vertebrae are reduced in size: they are less sacralized.

Taken together, these Pliocene and Early Pleistocene hominin axial specimens imply that 12 thoracics, six lumbars and four sacrals may have been either the modal pattern, or a significant pattern, prior to the later Pleistocene shift to modal five lumbars and five sacrals. Sanders ('95) has proposed a plausible functional-selection hypothesis for the shift. Greater numbers of lumbar vertebrae in hominins relative to apes is a way of achieving lumbar lordosis without excessive shear stress on intervertebral joints, and also balancing the torso on a relatively narrow suppport base during locomotion. In australopithecines, the last lumbar is situated clearly between the iliac blades (as in the rare chimpanzees with five lumbars. As hominins evloved larger bodies and probably more active locomotor repertoires, it is possible that changes in iliac shape and orientation provided greater freedom to the last lumbar vertebra. Selection would have favored integrating this element into the sacrum. Of course, more fossil material will be needed to test whether this scenario is morphologically supported. Whatever their functional cause, such changes could be readily explained developmentally through minor adjustments in expression domains of Hox-10 through -12 paralogues. 
What about the very first bipedally adapted hominins? Starting from the hypothesized ancestral T13, L4 or 3, S6 chimp-like modal pattern, with shorter and less mobile lumbar region, selection for efficient bipedalism would favor longer and more lordotic lumbar regions containing more elements (Robinson, '72; Lovejoy, '88; Sanders, '95). I hypothesize that this change would be accomplished in two steps rather than one, from the ancestral modal T13, L4 or 3, S6 to modal T13, L5, S5 or T12, L5, S5. The earliest bipedal hominins, when recovered, will test this hypothesis. A second step, completed by around 3 $\mathrm{Ma}$, would lead to modal T12, L6 or 5, S5 or 4 as found in Australopithecus and Homo erectus.

Considering this first hypothetical step from an apelike ancestor with four or three lumbars to an early hominin with five, it is worth noting that, although chimpanzees with five lumbars are very rare, they nonetheless do exist. One out of 17 Pan paniscus has a precaudal formula of 7:12:5:6 (Table 5). Of 179 Pan troglodytes, three have five lumbars, two with T13 and one with T12 (Table 3 ); one of these is the specimen documented by Tyson (1699). In addition, one specimen in the large Cleveland Museum collection (\#5430) has five lumbars (Lauren Stevens, pers. comm.). In all these specimens the most caudal two or even three lumbars lie well within the iliac blades. As Tyson (1699) noted: "The Vertebrae of the Loins.....number the fame, as in Man, viz. five........But the Os Ilium of each fide does not afend fo high, as to include the two latter Vertebrae; which is not fo in Man." Robinson's descriptions and illustrations of the Australopithecus africanus Sts 14 articulated lumbar spine and pelvis (Robinson, '72, Fig. 57) show that at least in this hominid the most caudal lumbar lies well within the iliac blades. Again, these hypothesized vertebral transpositions are readily achievable through modest shifts in expression domains of Hox genes (paralogues -9 though -12).

\section{DISCUSSION}

Experimental developmental research on primates is not feasible for several reasons, but the homologies across wide phylogenetic distances are sufficiently robust that one can imagine transgenic experiments using model species which mimic some of the key adaptive shifts in anthropoid evolution, including those of hominins. Of all the major adaptive complexes in which humans differ importantly from ancestors and relatives (brain size and structure, cultural and linguistic behavior, cranial, tooth and limb morphology, positional repertoire, alimentary system), axial involvement in positional behaviors is one which can be approached experimentally. The axial skeleton is an important component of a biologically important functional-behavioral system, the positional repertoire: bipedalism is one of the most distinctive markers of our lineage.

As I have shown, abundant data are available on intraspecific axial variability, particularly for hominoids, and the axial patterns of hominins as well as other anthropoid primates are reasonably well explained adaptively (Shapiro, '93). Phylogenetic relationships are robustly reconstructed, and axial patterns in living anthropoids, together with those of a few fossils, make it possible to hypothesize plausible morphotypes (ancestors). Enough is known already about the developmental genetics of the axial skeleton to generate reasonable hypotheses about the general mechanisms of intra- and interspecific variation.

Hypotheses about the (relatively minor) axial shifts reviewed here for anthropoids will be greatly improved as experiments in model organisms, especially the mouse, reconstruct more fully the genetic networks involved in somitogenesis and vertebral specification, and I hope that this paper might stimulate some further research along these lines. Of importance will be greater understanding of the developmental genetics and inheritance of intra-specific axial variation, perhaps taking advantage of the fact that a number of strains of laboratory mice are differently polymorphic for regional vertebral numbers, particularly in the lumbar region (Green, '54; Silver, '95). Identification of more key cis- and trans-regulatory elements involved in the Hox system, as well as other upstream and downstream genes, will be critical to better understanding of and hypothesizing about the kinds of primarily homeotic shifts documented here. For example, comparisons across mouse strains of regulatory elements might prove informative. Perhaps other experimental animals could be studied in which relevant axial polymorphisms have been recorded; for example, the laboratory rabbit (Sawin, '37).

Although experimental studies of primates are not practically or ethically feasible, in at least two species it is possible that progress can be made in understanding more about the genetic determinants specifically of axial variation. There are many human pathologies involving the vertebral column (see, for example, the data base OMIM, 
and also Filler, '93; Barnes, '94), and as their genetic bases are determined they can provide further sources of insight. As Carroll (2003, p. 857) notes: " $6 \times 10^{9}$ interbreeding humans is a very large resource for.....mapping genetic variation that underlies morphological variation...which could lead to genes that govern the formation of human traits and that might have played a part in hominid evolution". Rockman and Wray (2002) have shown that Homo sapiens is a particularly useful species for studying experimentally validated cis-regulation polymorphisms. In a second primate, baboons of the cercopithecoid genus Papio, which are polymorphic for number of lumbar vertebrae (roughly equal fractions of 6 or 7 ), can be traced through enough generations to make QTL mapping of relevant genetic regions feasible (Jeff Rogers, pers. comm.).

A major goal of genome research is now the identification of gene regulation networks. Levine and Tjian note (2003, p. 150), "Increasingly powerful methods of comparative genomics should identify many of the changes in cis-regulatory DNAs and general transcription complexes underlying animal diversity." As key regulatory sequences are increasingly elucidated in the mouse, and as complete or partial genome sequences become available in primates such as chimp, gorilla, and baboon, in addition to humans, it will be possible to locate homologous regulatory elements in these (and other) primates (see, for example, Chiu and Hamrick, 2002; Nobrega et al., 2003). Hox genes and their regulatory elements to target would include Hoxc-8, Hoxa-9, and Hoxc-9, expressed in the thoracic region and at the thoracic-lumbar boundary, and Hoxa-10, Hoxd10, and Hoxd-11, expressed around the lumbarsacral boundary. Hypotheses about the genetic bases of intraspecific variation and evolution of primate axial phenotypes involving these elements could then be tested in transgenic mice, for example, by using relevant human, chimp, and other species' regulatory sequences to test whether the modest shifts in thoracic, lumbar, or sacral regions are comprehensible as far as the known or hypothesized intra- or interspecific variation reviewed here is concerned.

\section{ACKNOWLEDGEMENTS}

I thank Dan Lieberman, Maryellen Ruvolo, Bill Sanders, and Nathan Young for discussion or reading drafts; Adrienne Zihlman, Colin Groves,
Bob Martin, Lauren Stevens, and Dan Gebo for sharing data; Judy Chupasko and Chris Helgren for help with Harvard Museum of Comparative Zoology collections; Jeff Rogers and Anne Burke for evo-devo advice; and Dan Lieberman for inviting and inciting this piece.

\section{LITERATURE CITED}

Ahn D-g, Gibson G. 1999a. Expression patterns of threespine stickleback Hox genes and insights into the evolution of the vertebrate body axis. Dev Genes Evol 209: 482-494.

Ahn D-g, Gibson G. 1999b. Axial variation in the threespine stickleback: relationship to Hox gene expression. Dev Genes Evol 209:473-481.

Ahn D-g, Gibson G. 1999c. Axial variation in the threespine stickleback: genetic and environmental factors. Evol Devel 1:100-112.

Aimi M. 1994. Numerical variation of vertebrae in Japanese macaques. Anthropol Sci 102 (suppl.): 1-10.

Allan D, Houle M, Bouchard N, Meyer B, Gruss P, Lohnes D. 2001. $R A R g$ and $C d x 1$ interactions in vertebral patterning. Dev Biol 240:46-60.

Allbrook D. 1955. The East African vertebral column: a study in racial variability. Amer J Phys Anth 13:489-514.

Arensburg B. 1991. The vertebral column, thoracic cage and hyoid bone. In Le squelette Moustérien de Kébara 2, pp. 113-146. Paris France: éditions du CNRS.

Arsuega J-L, Lorenzo C, Carretero J-M, Gracia A, Bermúdez de Castro J-M, Carbonell E. 1999. A complete human pelvis from the Middle Pleistocene of Spain. Nature 399: 255-258.

Arthur W. 2002. The emerging conceptual framework of evolutionary developmental biology. Nature 415:757-764.

Bar Yosef O, Vandermeersch B, editors. 1991. Le squelette Moustérien de Kébara 2. Paris: éditions du CNRS.

Bardeen C. 1904. Numerical vertebral variation in the human adult and embryo. Anat Anz 25:497-519.

Barnes E. 1994. Developmental defects of the axial skeleton in paleopathology. Niwot, CO: University of Colorado Press.

Belting H-G, Shashikant C, Ruddle F. 1998a. Multiple phases of expression and regulation of mouse Hoxc 8 during early embryogenesis. J Exp Zool 282:196-222.

Belting H-Gx, Shashikant C, Ruddle F. 1998b. Modification of expression and cis-regulation of $H o x c 8$ in the evolution of diverged axial morphology. Proc Natl Acad Sci USA 95:2355-2360.

Bermúdez de Castro JM, Martinón-Torres M, Sarmiento S, Lozano M, Arsuaga, JL, Carbonell E. 2003. Rates of anterior tooth wear in Middle Pleistocene hominins from Sima de los Huesos (Sierra de Atapuerca, Spain). Proc Natl Acad Sci USA 100:11992-11996.

Bradshaw M, Shashikant C, Belting H-G, Bollekens J, Ruddle F. 1996. A long range regulatory element of Hoxc8 identified by using the pClasper vector. Proc Natl Acad Sci USA 93:2426-2430.

Brown F, McDougall I. 1993. Geologic setting and age. In: Walker A, Leakey R, editors. The Nariokotome Homo erectus skeleton. Cambridge, MA: Harvard University Press. p 9-20. 
Burke A, Nelson C, Morgan B, Tabin C. 1995. Hox genes and the evolution of vertebrate axial morphology. Development 121:333-346.

Burke A, Nowicki J. 2001. Hox genes and axial specification in vertebrates. Amer Zool 41:687-697.

Calhoun V, Levine M. 2003. Long-range enhancer-promoter interactions in the Scr-Antp interval of the Drosophila Antennapedia complex. Proc Natl Acad Sci USA 100: 9878-9883.

Carroll S, Grenier J, Weatherbee S. 2001. From DNA to diversity. Malden, MA: Blackwell Science.

Carroll S. 2003. Genetics and the making of Homo sapiens. Nature 422:849-858.

Charité J, de Graaff W, Vogels R, Meijlink F, Deschamps J. 1995. Regulation of the Hoxb-8 gene: synergism between multimerized cis-acting elements increases responsiveness to positional information. Dev Biol 171:294-305.

Chen F-C, Li W-H. 2001. Genomic divergences between humans and other hominoids and the effective population size of the common ancestor of humans and chimpanzees. Amer J Hum Genet 68:444-456.

Chiu C-H, Hamrick M. 2002. Evolution and development of the primate limb skeleton. Evol Anth 11:94-107.

Christ B, Huang R, Wilting J. 2000. The development of the avian vertebral column. Anat Embryol 202:179-194.

Clauser D. 1980. Functional and comparative anatomy of the primate spinal column: some locomotor and postural adaptations. PhD dissertation, University of WisconsinMilwaukee. Ann Arbor MI: University Microfilms.

Dale J, Maroto M, Dequeant M-L, Malapert P, McGrew M, Pourquié O. 2003. Periodic Notch inhibition by Lunatic Fringe underlies the chick segmentation clock. Nature 421:275-278.

Darwin C. 1859. On the origin of species. (Facsimile of first edition) Cambridge, MA: Harvard University Press.

Davis AP, Capecchi MR. 1994. Axial homeosis and appendicular skeleton defects in mice with a targeted disruption of Hoxd-11. Development 120:2187-2198.

Dubrulle J, McGrew M, Pourquié O. 2001. FGF signalling controls somite boundary position and regulates segmentation clock control of spatiotemporal gene activity. Cell 106:219-232.

Dubrulle J, Pourquié O. 2004. fgf8 mRNA decay establishes a gradient that couples axial elongation to patterning in the vertebrate embryo. Nature 427:419-422.

Duday H, Arensburg B. 1991. La pathologie. In: Bar Yosef O, Vandermeersch B, editors. Le squelette Moustérien de Kébara 2. Paris: éditions du CNRS. p 179-193.

Erikson G. 1963. Brachiation in New World monkeys and in anthropoid apes. Symp Zool Soc Lond 10:135-163.

Favier B, Le Meur M, Chambon P, Dolle P. 1995. Axial skeleton homeosis and forelimb malformations in Hoxd-11 mutant mice. Proc Natl Acad Sci USA 92: 310-314

Filler A. 1993. Evolution of the sacrum in hominoids. In: Doty JR, Setti Sr, editors. Surgical disorders of the sacrum. New York: Thieme Medical Publishers. p 13-20.

Flower W. 1884. Catalogue of the specimens illustrating the osteology and dentition of the vertebrated animals, recent and extinct, contained in the museum of the Royal College of Surgeons of England, Part II. Mammalia.

Gagneux P, Wills C, Gerloff U, Tautz D, Morin PA, Boesch C, Fruth B, HohmannGx, Ryder OA, Woodruff DS. 1999. Mitochondrial sequences show diverse evolutionary his- tories of African hominoids. Proc Natl Acad Sci USA 96:5077-5082.

Gellon G, McGinnis M. 1998. Shaping animal body plans in development and evolution by modulation of Hox expression patterns. BioEssays 20:116-125.

Gérard M, Zákány J, Duboule D. 1997. Interspecies exchange of a Hoxd enhancer in vivo induces premature transcription and anterior shift of the sacrum. Dev Biol 190: $32-40$.

Goodman M, Porter CA, Czelusniak J, Page SL, Schneider H, Shoshani J, Gunnell G, Groves CP. 1998. Toward a phylogenetic classification of primates based on DNA evidence complemented by fossil evidence. Mol Phylog Evol 9:585-598.

Goodman F, Scandler P. 2001. Human HOX gene mutation. Clin Genet 59:1-11.

Green E. 1954. Quantitative genetics of skeletal variations in the mouse. I. Crosses between three short-eared strains (P, NB, SEC/2). J Nat Cancer Inst 15:609-627.

Groves CP. 1972. Systematics and phylogeny of gibbons. In: Rumbaugh D, editor. Gibbon and Siamang, vol.1. Basel: Karger. p 2-89.

Haack H, Kessel M. 1994. Homeobox genes and skeletal patterning. In: Hall B, editor. Bone, Volume 9: Differentiation and morphogenesis of bone. Boca Raton, LA: CRC Press. p 119-144.

Hanson R, Hess J, Yu B, Ernst P, van Lohuizen M, Berns A, van der Lugt $\mathrm{N}$, Shashikant $\mathrm{Cx}$, Ruddle F, Seto M, Korsmeyer S. 1999. Mammalian Trithorax and Polycombgroup homologues are antagonistic regulators of homeotic development. Proc Nat Acad Sci USA 96:14372-14377.

Hasebe K. 1913. Die wirbelsäule der Japaner. Zeit Morph Anth 15:259-380.

Hauesler M, Martelli S, Boeni T. 2002. Vertebrae numbers of the early hominid lumbar spine. J Hum Evol 43: 621-644.

Hérault Y, Beckers J, Gérard M, Duboule D. 1999. Hox gene expression in limbs: colinearity by opposite regulatory controls. Dev Biol 208:157-165.

Hildebrand M. 1988. Analysis of vertebrate structure. New York: John Wiley\&Sons.

Ishida H, Kunimatsu Y, Takano T, Nakano Y, Nakatsuka M. 2004. Nacholapithecus skeleton from the Middle Miocene of Kenya. J Hum Evol 46:69-103.

Johanson D, Lovejoy C, Kimbe W, White T, Bush M, Latimer B, Coppens Y. 1982. Morphology of the Pliocene partial hominid skeleton (A.L. 288-1) from the Hadar Formation, Ethiopia. Amer J Phys Anth 57:403-451.

Kessel M. 1992. Respecification of vertebral identities by retinoic acid. Development 115:487-501.

Kimbel W, Johanson D, Rak Y. 1994. The first skull and other new discoveries of Australopithecus afarensis at Hadar, Ethiopia. Nature 368:449-451.

Kornak U, Mundlos, S. 2003. Genetic disorders of the skeleton: a developmental approach. Am J Hum Genet 73:447-474.

Latimer B, Ward CV. 1993. The thoracic and lumbar vertebrae. In: Walker A, Leakey R, editors. The Nariokotome Homo erectus skeleton. Cambridge, MA: Harvard University Press. p 266-293.

Levine M, Tjian R. 2003. Transcription regulation and animal diversity. Nature 424:147-151.

Lewis EB. 1978. A gene complex controlling segmentation in Drosophila. Nature 276:565-570. 
Lovejoy CO. 1988. Evolution of human walking. Sci Amer 259:118-125.

McHenry H, Berger L. 1996. Ape-like body proportions in A. africanus and their implications for the origin of the genus Homo. Amer J Phys Anth (Suppl.) 22:163-164.

McPherron A, Lawler A, Lee S-J. 1999. Regulation of anterior/ posterior patterning of the axial skeleton by growth/ differentiation factor 11. Nature Gen 22:260-264.

Moyà-Solà S, Köhler M. 1996. The first Dryopithecus skeleton: Origins of great ape locomotion. Nature 379:156-159.

Nakatsukasa M, Tsujikawa H, Shimuzu D, Takano T, Kunimatsu Y, Nakano Y, Ishida H. 2003. Definitive evidence for tail loss in Nacholapithecus, and East African Miocene hominoid. J Hum Evol 45:179-186.

Nei M. 1987. Molecular evolutionary genetics. New York: Columbia University Press.

Nobrega MA, Ovcharenko I, Afzal V, Rubin EM. 2003. Scanning human gene deserts for long-range enhancers. Science 302:413.

OMIN (Online Mendelian Inheritance in Man) http:// www.ncbi.nlm.gov/Omim/.

Paterson A. 1893. The human sacrum. Sci Trans Royal Dublin Soc 5:123-204.

Pellegrini M, Pantano S, Fumi M, Lucchini F, Forabosco A. 2001. A genesis of the scapula in Emx2 homozygous mutants. Dev Biol 232:149-156.

Pilbeam D. 1996. Genetic and morphological records of the Hominoidea and hominid origins: a synthesis. Mol Phylog Evol 5:155-168.

Pilbeam D. 2002. Perspectives on the Miocene Hominoidea. In: Hartwig W, editor. The Primate Fossil Record, ed. W. Hartwig. Cambridge, MA: Cambridge University Press. p 303-310.

Pourquié O. 2001. Vertebrate somitogenesis. An Rev Cell Dev Biol 17:311-350.

Rak Y. 1991. The pelvis. In: Bar Yosef O, Vandermeersch B, editors. Le squelette Moustérien de Kébara 2. Paris: éditions du CNRS. p 147-156.

Robinson J. 1972. Early hominid posture and locomotion. Chicago: University of Chicago Press.

Rockman M, Wray G. 2002. Abundant raw material for cis-regulatory evolutionin humans. Mol Biol Evol 19: 1991-2004.

Rose MD, Ishida H, Nakano Y. 1996. Kenyapithecus postcranial specimens from Nachola. Kenya Afr Stud Monogr Suppl 24:3-56.

Ruvolo M. 1997a. Molecular phylogeny of the Hominoids: Inference from multiple independent DNA sequence data sets. Mol Biol Evol 14:248-265.

Ruvolo M. 1997b. Genetic diversity in hominoid primates. Ann Rev Anth 26:515-540.

Saga Y, Takeda H. 2001. The making of the somite: molecular events in vertebrate segmentation. Nature Rev Genet $2: 835-845$.

Sanders W. 1995. Function, allometry, and evolution of the australopithecine lower precaudal spine. Ph.D. dissertation, New York University.

Sanders W. 1998. Comparative morphometric study of the australopithecine vertebral series Stw-H8/H41. J Hum Evol 34:249-302.

Sanders W, Bodenbender B. 1994. Morphometric analysis of lumbar vertebra UMP 67-28:implications for spinal function and phylogeny of the Miocene Moroto hominoid. J Hum Evol 26:203-237.
Sawin P. 1937. Preliminary studies of hereditary variation in the axial skeleton of the rabbit. Anat Rec 69:407-428.

Schultz A. 1930. The skeleton of the trunk and limbs of higher primates. Hum Biol 2:303-438.

Schultz A. 1933. Observations on the growth, classification and evolutionary specialization of gibbons and siamangs (concluded). Hum Biol 5:385-428.

Schultz A. 1961. Vertebral column and thorax. Primatologia 4:1-66.

Shapiro L. 1993. Functional morphology of the vertebral column in primates. In: Gebo D, editor. Postcranial adaptation in nonhuman primates. DeKalb: Northern Illinois Unversity Press. p 121-149.

Sharpe K, Nonchev S, Gould A, Whiting J, Krumlauf R. 1998. Selectivity, sharing and competitive interactions in the regulation of Hoxb genes. EMBO 17:1788-1798.

Shashikant C, Ruddle F. 1996. Combinations of closely situated cis-acting elements determine tissue-specific patterns and anterior extent of early Hoxc8 expression. Proc Natl Acad Sci USA 93:12364-12369.

Silver L. 1995. Mouse genetics. Oxford: Oxford University Press.

Slijper E. 1946. Comparative biologic-anatomical investigations on the vertebral column and spinal musculature of mammals. Verh Kon Ned Akad Wet (TweedeSectie) 42: 1-128.

Solounias N. 1999. The remarkable anatomy of the giraffe's neck. J Zool Lond 247:257-268.

Spitz F, Gonzalez F, Peichel C, Vogt T, Duboule D, Zákány J. 2001. Large scale transgenic and cluster deletion analysis of the Hoxd complex separate an ancestral regulatory module from evolutionary innovations. Genes Develop 15:22092214.

Stollewerk A, Schoppmeier M, Damen W. 2003. Involvement of Notch and Delta genes in spider segmentaiton. Nature 423:863-865.

Swindler D, Wood C. 1973. An atlas of primate gross anatomy. Seattle: University of Washington Press.

Todd TW. 1922. Numerical significance in the thoracilumbar vertebrae of the Mammalia. Anat Rec 24:261-286.

Tyson E. 1699. Anatomy of a Pygmie. Facsimile Edition, 1966. London: Dawsons of Pall Mall.

Todaro GJ. 1980. Evidence using viral gene sequences suggesting an Asian origin of man. In Current argument on early man, ed., L.-K. Konigsson, pp. 252-260. Oxford UK: Pergamon.

Trinkaus E. 1983. The Shanidar neandertals. New York: Academic Press.

Vasiliauskas D, and Stern C. 2001. Patterning the embryonic axis: $F G F$ signalling and how vertebrate embryos measure time. Cell 106:133-136.

Veraksa A, Del Campo M, McGinnis W. 2000. Developmental patterning genes and their conserved functions: from model organisms to humans. Mol Genet Metab 69:85-100.

Wahba G, Hostikka S, Carpenter E. 2001. The paralogous Hox genes Hoxa10 and Hoxd10 interact to pattern the mouse hindlimb peripheral nervous system and skeleton. Dev Biol 231:87-102.

Walker A, Leakey R. 1993. The postcranial bones. In: Walker A, Leakey R, editors. The Nariokotome Homo erectus skeleton. Cambridge, MA: Harvard University Press. p 95-160.

Walker A, Ruff C. 1993. The reconstruction of the pelvis. In: Walker A, Leakey R, editors. The Nariokotome Homo 
erectus skeleton. Cambridge, MA: Harvard University Press. p 221-233.

Ward C. 1993. Torso morphology and locomotion in Proconsul nyanzae. Amer J Phys Anth 92:291-328.

Ward C, Walker A, Teaford M. 1991. Proconsul did not have a tail. J Hum Evol 21:215-220.

Washburn S. 1963. Behavior and human evolution. In: Classification and human evolution, Washburn SL, ed., pp. 190-203. Chicago, IL: Aldine.

Wellik D, Capecchi M. 2003. Hox10 and Hox11 genes are required to globally pattern the mammalian skeleton. Science 301:363-367.

Wilson D. 1972. Tail reduction in Macaca. In: The functional and evolutionary biology of Primates, ed., R. Tuttle, pp. 241261. Chicago IL: Aldine.
Yu B, Hess J, Horning S, Brown G, Korsmeyer S. 1995. Altered Hox expression and segmental identity in $\mathrm{Mll}$ mutant mice. Nature 378:505-508.

Zákány J, Gérard M, Favier B, Duboule D. 1997. Deletion of a Hoxd enhancer induces transcriptional heterochrony leading to transposition of the sacrum. EMBO 16:4393-4402.

Zákány J, Kmita M, Alarcon P, de la Pompa J-L, Duboule D. 2001. Localized and transient transcription of Hox genes suggests a link between patterning and the segmentation clock. Cell 106:207-217.

Zapfe H. 1960. Die Primatenfunde aus der miozänen Spaltenfüllung von Neudorfan der March (Devinská Nová Ves), Tschechoslowakei. Schweiz Palaeont Abhand 78:1-293.

Zhao Y, Potter S. 2001. Functional specificity of the Hoxa13 homeobox. Development-Suppl 128:3197-3207. 